\title{
Regulating DNA Replication in Eukarya
}

\author{
Khalid Siddiqui, Kin Fan On, and John F.X. Diffley \\ Cancer Research UK, London Research Institute, Clare Hall Laboratories, South Mimms, \\ Herts EN6 3LD, United Kingdom \\ Correspondence: John.Diffley@cancer.org.uk
}

DNA replication is tightly controlled in eukaryotic cells to ensure that an exact copy of the genetic material is inherited by both daughter cells. Oscillating waves of cyclin-dependent kinase (CDK) and anaphase-promoting complex/cyclosome (APC/C) activities provide a binary switch that permits the replication of each chromosome exactly once per cell cycle. Work from several organisms has revealed a conserved strategy whereby inactive replication complexes are assembled onto DNA during periods of low CDK and high APC activity but are competent to execute genome duplication only when these activities are reversed. Periods of high CDK and low APC/C serve an essential function by blocking reassembly of replication complexes, thereby preventing rereplication. Higher eukaryotes have evolved additional CDK-independent mechanisms for preventing rereplication.

$\mathrm{T}^{\mathrm{h}}$ he Eukarya include a wide spectrum of organisms, with genome sizes ranging from $\sim 10^{7}$ bp in yeasts to $\sim 10^{12}$ bp in protozoa. Rapid duplication of large genomes is achieved by distribution of the genetic material across several chromosomes. Each of these chromosomes initiates replication from sites called replication origins, which must fire no more than once per cell cycle to ensure a single error-free copy of the genome. Generating replication forks from an origin more than once leads to rereplication, an event that creates multiple copies of a single genomic region within a single cell. This leads to gene amplification and promotes genome instability (Green et al. 2010), a phenomenon observed in many human cancers (Lengauer et al. 1998). The process of genome duplication is therefore under stringent control to ensure that few, if any, defects are transmitted from one generation to the next.

\section{GENERAL STRATEGY FOR INITIATION OF EUKARYOTIC DNA REPLICATION}

Origin Licensing: Loading of the Replicative Helicase

Eukaryotic cells initiate DNA replication in two discrete steps. First, an inactive form of the replicative helicase is assembled onto doublestranded DNA (dsDNA) in a process called origin licensing. This occurs during late mitosis and $\mathrm{G}_{1}$ phase of the cell cycle. The six-subunit origin-recognition complex (ORC) binds to DNA sequences called origins of replication and recruits the Cdc6 and Cdt1 proteins. Together these three licensing factors direct the loading of the helicase, the minichromosome maintenance (MCM) complex, around dsDNA. The MCM complex thus loaded is topologically linked to DNA and forms a double hexamer (Donovan et al. 1997; Rowles et al. 1999; Seki

Editors: Stephen D. Bell, Marcel Méchali, and Melvin L. DePamphilis

Additional Perspectives on DNA Replication available at www.cshperspectives.org

Copyright (C) 2013 Cold Spring Harbor Laboratory Press; all rights reserved; doi: 10.1101/cshperspect.a012930

Cite this article as Cold Spring Harb Perspect Biol 2013;5:a012930 
K. Siddiqui et al.

and Diffley 2000; Evrin et al. 2009; Remus et al. 2009; Gambus et al. 2011). This form of the inactive helicase is also referred to as the prereplicative complex (pre-RC).

\section{Origin Firing: Activation of the Replicative} Helicase

During $\mathrm{S}$ phase, the inactive pre- $\mathrm{RC}$ is converted into an active helicase that unwinds dsDNA, thus allowing DNA polymerases to access and copy the two template strands. This second step of origin firing involves the formation of the CMG complex, named after its components: Cdc45, the MCM proteins, and the GINS complex (Moyer et al. 2006; Aparicio et al. 2009). The active CMG helicase is then coupled to a DNA polymerase, either Pol $\varepsilon$ for the leading strand or Pol $\delta$ for the lagging strand (Kunkel and Burgers 2008). This process requires the activity of the Sld2, Sld3, Sld7, and Dpb11 proteins as well as the two protein kinases cyclindependent kinase (CDK) and Dbf4-dependent kinase (DDK) (Bousset and Diffley 1998; Kamimura et al. 1998; Zou and Stillman 1998, 2000; Kamimura et al. 2001; Masumoto et al. 2002; Tanaka et al. 2007; Zegerman and Diffley 2007;
Tanaka et al. 2011b). These six firing factors are essential for initiating DNA synthesis from licensed origins.

\section{CELL-CYCLE CONTROL OF THE INITIATION OF DNA REPLICATION}

\section{Control of Initiation of Replication during an Unperturbed Cell Cycle}

The two steps of initiation described above are isolated from each other in different stages of the cell cycle. No origin firing can be allowed in $\mathrm{G}_{1}$ while pre-RC complexes are assembled, lest there be regions of the genome that have not been properly licensed. Conversely, no origin licensing can be permitted during $\mathrm{S}$ phase while origin activation is triggered (Fig. 1). This ensures that multiple replication forks do not initiate from the same origin, thus preventing rereplication. Insulation of these two steps is achieved by the concerted action of two enzyme complexes: the CDK and the anaphase-promoting complex/cyclosome (APC/C).

Eukaryotes express different cyclin proteins during different stages of the cell cycle, leading to cell cycle stage-specific cyclin-CDK complexes

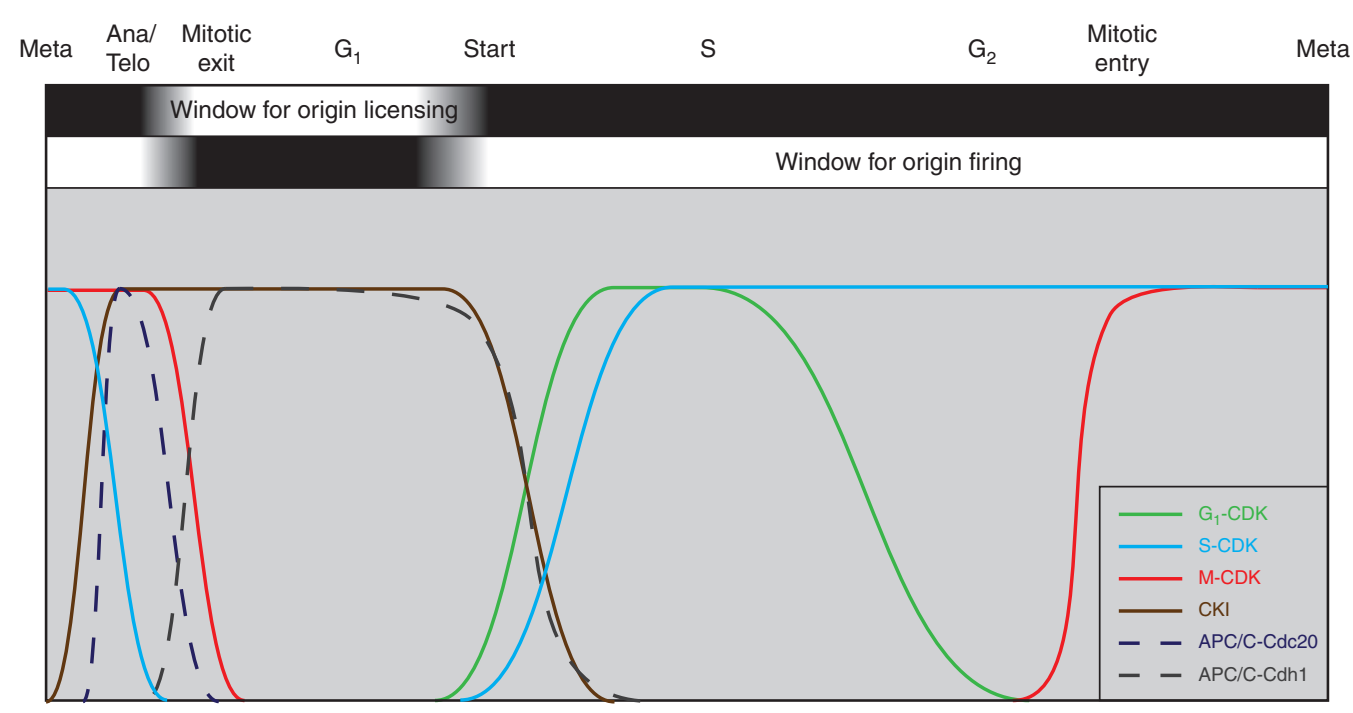

Figure 1. Regulation of DNA replication in the cell cycle. A generic diagram summarizing the oscillation of CDK activity in the cell cycle in response to the fluctuation of APC/C activity and the presence of CDK inhibitor (CKI). The details of regulation in different organisms are described in the corresponding sections of the article. 
(Table 1). The cyclin subunit of the CDK contributes to determining substrate specificity, thus resulting in cell cycle stage-dependent phosphorylation of different target proteins. $\mathrm{G}_{1^{-}}$ phase cyclin-CDKs $\left(\mathrm{G}_{1}-\mathrm{CDKs}\right)$ phosphorylate proteins to promote S-phase entry, S-phase cyclin-CDKs (S-CDKs) are required to activate DNA replication, and mitotic cyclin-CDKs (MCDKs) regulate accurate chromosome segregation through mitosis. Although different cyclins can confer some substrate specificity, experiments in fission yeast have shown that a single cyclin-CDK fusion can support a near-normal cell cycle (Coudreuse and Nurse 2010).

The APC/C is a multisubunit E3 ubiquitin ligase that polyubiquitinates different proteins targeted to it by a substrate adaptor (e.g., Cdc20 or Cdh1) (Peters 2006). The resulting proteinubiquitin conjugates are then degraded by the proteasome. The S-phase and $\mathrm{G}_{2} / \mathrm{M}$-phase cyclins are targeted for APC/C-mediated degradation. $\mathrm{G}_{1}$-phase cyclins are resistant to such regulation. Instead, they are processed for degradation during $\mathrm{S}$ phase by a different $\mathrm{E} 3$ ligase, the Skp1-Cul1-F-box protein (SCF) complex (Ang and Wade Harper 2005).

$\mathrm{M}$-CDK-dependent phosphorylation of the APC/C results in activation of this E3 ligase (Rudner and Murray 2000; Kraft et al. 2003). This results in ubiquitination of S-phase and $\mathrm{G}_{2} / \mathrm{M}$-phase cyclins, leading to their degradation and a subsequent loss of associated S-CDK and M-CDK activity. Mitosis ensues and is followed by a period of high APC/C-Cdh1 activity that defines the $G_{1}$ phase in cycling cells and the $\mathrm{G}_{0}$ phase in differentiated/quiescent cells. In actively proliferating cells, growth factor stimulation induces transcription of $G_{1}$-phase cyclins, resulting in an accumulation of $\mathrm{G}_{1}-\mathrm{CDK}$ activity. Phosphorylation of the APC/C adaptor
Cdh1 by $\mathrm{G}_{1}$-CDK prevents it from binding to and activating the APC/C, effectively inhibiting its function and allowing S-CDK activity to accumulate (Zachariae et al. 1998; Jaspersen et al. 1999). S-CDK then inhibits and switches off the APC/C during $S$ and $G_{2}$ phases. Hence, CDK and $\mathrm{APC} / \mathrm{C}$ enzymes regulate each other, and their peak activity times are mutually exclusive in the cell cycle, setting up biphasic oscillations (Fig. 1). Vertebrate cells have additionally evolved proteins that inhibit APC/C function during $S$ phase, such as Emil and Emi2 (Reimann et al. 2001; Tung et al. 2005). During prometaphase, Cdc2 and Plk1 cooperate to phosphorylate these inhibitors, presenting them for $\mathrm{SCF}^{\beta-\mathrm{TrCP}}$-mediated degradation, thus relieving the inhibition of the APC/C and promoting mitosis (Nakayama and Nakayama 2006).

Origin licensing occurs exclusively during late mitosis and $\mathrm{G}_{1}$, when $\mathrm{APC} / \mathrm{C}$ activity is high and S-CDK activity is low. S-CDK phosphorylation inhibits pre-RC assembly during $\mathrm{S}$, $\mathrm{G}_{2}$, and $\mathrm{M}$ phases, and thus all origins must be licensed before cells can enter $\mathrm{S}$ phase, because high CDK activity in the rest of the cell cycle would prevent any further licensing. If large regions of a chromosome are left unlicensed, it is possible that adjacent replication forks are unable to travel far enough to fuse into each other, leaving unreplicated stretches of DNA in between (Blow et al. 2011). Hence, several origins are licensed but only subsets are used to generate replication forks in every cell cycle, leaving clusters of dormant origins as a backup system. This ensures that every last base of the parental DNA gets copied. Pre-RCs that do not fire normally get displaced by passing replication forks, thus marking chromosome regions that have already been duplicated. Because many more origins need to be licensed than are used per cell divi-

Table 1. Regulators of cyclin-dependent kinase (CDK) in different organisms

\begin{tabular}{llcl}
\hline & \multicolumn{1}{c}{ Saccharomyces cerevisiae } & Schizosaccharomyces pombe & \multicolumn{1}{c}{ Metazoans } \\
\hline $\mathrm{G}_{1}$-CDK & $\mathrm{Cln} 1, \mathrm{Cln} 2, \mathrm{Cln} 3-\mathrm{Cdc} 28$ & Cig1, Puc1-Cdc2 & Cyclin D-CDK4, cyclin E-CDK2 \\
S-CDK & Clb5, Clb6-Cdc28 & Cig2-Cdc2 & Cyclin A-CDK2 \\
M-CDK & Clb1, Clb2, Clb3, Clb4-Cdc28 & Cig2, Cdc13-Cdc2 & Cyclin A-CDK1, cyclin B-CDK1 \\
CKI & Sic1 & Rum1 & p21, p27 \\
\hline
\end{tabular}

CKI, CDK inhibitor. 
K. Siddiqui et al.

sion, it is proposed that cells are prevented from entering $\mathrm{S}$ phase until complete assembly of replication complexes (Shreeram et al. 2002) and that conditions that decrease the total number of active replication complexes may result in genome instability (Kawabata et al. 2011).

\section{Control of DNA Replication on Exposure to Genotoxic Stress}

Cells have evolved checkpoint pathways to respond to external genotoxic insults by arresting the cell cycle, so that the cell can pause replication and correct mutations and lesions rather than segregating chromosomes with errors to daughter cells (Harper and Elledge 2007). The S-phase checkpoint acts to prevent licensed origins from firing and also stabilizes ongoing replication forks so that polymerases may resume activity once the damage has been corrected; these details are discussed in a separate article.

\section{REGULATION OF REPLICATION INITIATION IN Saccharomyces cerevisiae}

\section{Cell-Cycle Regulation of Pre-RC Assembly}

On exit from mitosis, CDK activity is lowered in two ways: by ubiquitin-mediated degradation of mitotic cyclin $\mathrm{Clb} 2$ by the $26 \mathrm{~S}$ proteasome (Schwab et al. 1997; Visintin et al. 1997) and by Sicl inhibition of $\mathrm{G}_{1}-\mathrm{CDK}_{\text {activity (Nugroho and }}$ Mendenhall 1994; Schwob et al. 1994). During this period, the Cdc14 phosphatase also promotes pre-RC assembly. First, it dephosphorylates Cdh1, thereby promoting its association with APC/C (Visintin et al. 1998; Zachariae et al. 1998; Jaspersen et al. 1999). Cdc14 also dephosphorylates the transcription factor Swi5, promoting its nuclear localization to activate transcription of Sic1 and Cdc6 (Knapp et al. 1996; Visintin et al. 1998). Finally, Cdc14 dephosphorylates Sic1, stabilizing it from $\mathrm{SCF}^{\mathrm{Cdc} 4}$-mediated degradation (Visintin et al. 1998). Cdc6 also acts as an M-CDK inhibitor by direct binding to Clb2 (Elsasser et al. 1996; Calzada et al. 2001).

During $G_{1}$ phase a cell begins the next complete round of cell cycle on reaching a sufficiently large cell size (Skotheim et al. 2008). Passage through the point of no return, or "Start," is initiated by the $\mathrm{G}_{1}-\mathrm{CDK} \mathrm{Cln}-\mathrm{Cdc} 28$ (Tyers et al. 1993; Dirick et al. 1995; Stuart and Wittenberg 1995). Two transcription factor complexes, SBF (Swi4-Swi6) and MBF (Mbp1-Swi6), are activated by phosphorylation of their allosteric inhibitor Whi5 (Costanzo et al. 2004; de Bruin et al. 2004). Whereas SBF activates transcription of Cln cyclins (Nasmyth and Dirick 1991; Spellman et al. 1998; Eser et al. 2011), MBF promotes transcription of Clb5 along with other replication genes (Lowndes et al. 1992; Koch et al. 1993; Spellman et al. 1998; Eser et al. 2011).

A key barrier to origin firing during $\mathrm{G}_{1}$ phase is the CDK inhibitor Sic1, which must be degraded before cells can initiate DNA synthesis (Donovan et al. 1994; Schwob et al. 1994; Schneider et al. 1996). Simultaneous phosphorylation on multiple CDK consensus sites by $\mathrm{Cln}-\mathrm{Cdc} 28$ and Clb-Cdc28 targets Sic1 for SCF-mediated polyubiquitination and proteolysis (Feldman et al. 1997; Verma et al. 1997a,b; Koivomagi et al. 2011a).

Another barrier to origin firing in $\mathrm{G}_{1}$ phase is APC/C-Cdh1 activity, which actively degrades $\mathrm{Clb}$ cyclins. During late $\mathrm{G}_{1}$ phase $\mathrm{Cln} 2$ Cdc28 and Clb5-Cdc28 phosphorylate Cdh1 and prevent its association with APC/C (Zachariae et al. 1998; Jaspersen et al. 1999). This allows accumulation of Clb5-Cdc28 activity essential for origin firing.

\section{CDK Control of Origin Licensing}

CDK phosphorylates several initiation proteins to inhibit pre- $\mathrm{RC}$ assembly. Clb-Cdc28 is recruited to ORC in an RxL-dependent manner (Weinreich et al. 2001; Wilmes et al. 2004) and phosphorylates Orc2 and Orc6 (Nguyen et al. 2001). These mechanisms inhibit interaction between ORC and Cdt1 (Chen et al. 2007), impeding loading of MCM complexes onto DNA (Chen and Bell 2011).

Cln-Cdc28 and Clb-Cdc28 phosphorylate Cdc6 to promote its subsequent degradation by the $\mathrm{SCF}^{\mathrm{Cdc} 4}$ complex (Drury et al. 1997, 2000; Elsasser et al. 1999; Perkins et al. 2001). During mitosis, binding of $\mathrm{Clb} 2$ to phosphorylated Cdc6 not only protects itself from SCF- 
mediated degradation but also prevents Cdc6 from interacting with ORC, rendering Cdc6 inactive for pre-RC assembly (Mimura et al. 2004). On mitotic exit, degradation of $\mathrm{Clb} 2$ by the APC/C releases Cdc6 to promote pre-RC assembly in the subsequent $\mathrm{G}_{1}$ phase.

As a result of a stable interaction with the MCM complex, Cdt 1 and MCM are regulated as a single unit in budding yeasts (Tanaka and Diffley 2002). Phosphorylation of CDK consensus sites in $\mathrm{Mcm} 3$ results in soluble Cdt1/ Mcm2-7 being transported out of the nucleus (Labib et al. 1999; Nguyen et al. 2000; Liku et al. 2005), where they are retained during $G_{2}$. Interestingly, every cell cycle requires a new round of MCM gene transcription, and "old" MCM proteins are degraded by ubiquitin-mediated proteolysis at the end of mitosis (Cheng et al. 2002; Braun and Breeden 2007).

CDK phosphorylation of pre-RC components is the primary barrier to rereplication in budding yeasts. The inhibition of ORC, Cdc6, and Cdt1 creates redundant pathways that must be simultaneously deregulated to result in significant overreplication of DNA in a single cell (Nguyen et al. 2001). Yeast strains that are mutated in either one or two of these modules show undetectable or mild rereplication phenotypes (Green et al. 2006), suggesting that CDK-mediated prevention mechanisms work together to ensure that rereplication becomes an extremely rare event (Diffley 2011).

\section{CDK Control of Origin Firing}

Phosphorylation of Sld2 and Sld3 by S-CDK promotes interaction of these proteins with the amino-terminal and carboxy-terminal BRCT domains of Dpb11, respectively (Tanaka et al. 2007; Zegerman and Diffley 2007; Muramatsu et al. 2010). Cln-Cdc28 cannot phosphorylate Sld 2 and Sld 3 during $G_{1}$ phase, possibly because of substrate specificity conferred by cyclin (Koivomagi et al. 2011b).

Yeast strains expressing an Sld3-Dpb11 fusion protein in combination with a phosphomimetic mutant of Sld2 can promote CDK-independent DNA synthesis in $\mathrm{G}_{1}$-arrested cells, thereby bypassing the requirement for S-CDKs
(Zegerman and Diffley 2007). This indicates that Sld2 and Sld3 are the minimal set of CDK substrates required for DNA replication. Interestingly, the Jet 1 allele of Cdc45 bypasses the Sld3 phosphorylation requirement for cell survival, thus implicating Cdc45 in the interaction between Sld3 and Dpb11 (Tanaka et al. 2007).

\section{DDK Control of Origin Firing}

The first evidence that DDK promotes initiation via $\mathrm{Mcm} 2-7$ came from the isolation of a mutant allele of Mcm5 (mom5-bob1), which bypassed the requirement for DDK (Hardy et al. 1997). Purified DDK phosphorylates Mcm2, $\mathrm{Mcm} 4$, and Mcm6 subunits within double hexamers bound to DNA and has weak or no activity toward subunits within soluble hexamers (Francis et al. 2009). DDK phosphorylation of an amino-terminal region in $\mathrm{Mcm} 4$ facilitates $\mathrm{Mcm}-\mathrm{Cdc} 45$ complex formation during S phase (Sheu and Stillman 2006). Mutational analysis of $\mathrm{Mcm} 4$ reveals that the unstructured amino terminus of this protein contains an inhibitory activity that is alleviated on DDK phosphorylation. Accordingly, deletion of this region results in an $\mathrm{Mcm} 4$ protein that promotes DDK-independent DNA synthesis in cells arrested at $G_{1}$ phase and rescues the viability of strains lacking functional DDK (Sheu and Stillman 2010). These data suggest that $\mathrm{Mcm} 2,-4$, and -6 are essential substrates for DDK in vivo. The exact mechanism by which DDK promotes origin firing is currently unclear and may involve the recruitment of firing factors such as Sld3, Sld7, and Cdc45 to origins (Tanaka et al. 2011a) perhaps via a DDK-phosphorylated MCM complex.

Activity of DDK is restricted to $S$ phase as a result of APC/C-mediated degradation of the regulatory Dbf4 subunit (Oshiro et al. 1999; Weinreich and Stillman 1999; Ferreira et al. 2000). This has been proposed to prevent premature firing of origins during $\mathrm{G}_{1}$ phase. Although expression of a nondegradable Dbf4 mutant does not induce significant rereplication (Ferreira et al. 2000), overproduction of Dbf4 in the CDK bypass yeast strain (see above) is lethal (Zegerman and Diffley 2007). This 
K. Siddiqui et al.

observation highlights the importance of regulated origin firing to prevent premature initiation events during $G_{1}$ phase.

\section{REGULATION OF INITIATION IN \\ Schizosaccharomyces pombe}

\section{Origin Licensing in Fission Yeasts}

In Schizosaccharomyces pombe origin licensing requires the combined actions of ORC (Orp1 to -6), Cdc18, Cdt1, and the MCM complex (Hofmann and Beach 1994; Nishitani and Nurse 1995; Grallert and Nurse 1996; Maiorano et al. 1996; Muzi Falconi et al. 1996; Ogawa et al. 1999; Nishitani et al. 2000). No consensus autonomously replicating sequence has been defined for this species, and ORC binds to AT-rich sequences in the genome by virtue of nine AThook motifs on the amino terminus of Orp4 (Chuang and Kelly 1999; Kong and DePamphilis 2001; Lee et al. 2001; Hayashi et al. 2007). Accordingly, the binding to AT-rich sequences by Orp4 is ATP-independent (Chuang and Kelly 1999), whereas ORC in budding yeasts binds to origin DNA in the ATP-bound state (Bell and Stillman 1992; Klemm and Bell 2001). However, the evolutionary conservation of the ATP-binding sites in ORC suggests an essential role of the ATPase activity in licensing, most likely during the loading of the MCM helicase.

\section{Origin Firing in Fission Yeasts}

In fission yeasts Hsk1 activity is required for Sld3 recruitment to origins during $G_{1}$ phase (Nakajima and Masukata 2002), but Sld3 associates with origins independently of Sna41 (Yamada et al. 2004). This is followed by the sequential recruitment of Cut5, GINS, and Sna41 (Dolan et al. 2004; Yabuuchi et al. 2006). Cdc23 is also required for Sna41 association within the preinitiation complex (pre-IC) (Gregan et al.2003). However, the details of how the replicative helicase is activated currently remain unclear.

\section{CDK Control of Origin Licensing}

Orp2 is phosphorylated by Cdc2 in vivo, and a fission yeast strain expressing a nonphosphory- latable Orp2 protein is sensitized to rereplication (Vas et al. 2001). Overexpression of Cdc18 in such a strain results in more rereplication than that observed on overexpression in a wild-type strain. This suggests that CDK phosphorylation of Orp 2 is redundant with Cdc18 regulation in rereplication control in fission yeasts. The mitotic cyclin $\mathrm{Cdc} 13$ localizes to replication origins in an ORC-dependent manner during $\mathrm{G}_{2}$ phase and early mitosis. A yeast strain expressing a tagged Orp 2 that reduces $\mathrm{Cdc} 13$ origin association shows hypersensitivity to endoreduplication, suggesting a role for Orp2-Cdc13 association in rereplication control (Wuarin et al. 2002). The mechanism behind this regulation is currently unknown, but it is possible that direct binding of $\mathrm{Cdc} 13$ to Orp 2 somehow reduces the accessibility of other pre-RC assembly factors to ORC. This scenario is similar to the Clb5Orc6 and Clb2-Cdc6 interactions in budding yeasts, where direct binding may play a role in inhibiting factors involved in pre-RC assembly (see above).

Cdc18 is an unstable protein, and its levels are regulated throughout the cell cycle. $\mathrm{Cdc18}$ accumulation begins in late mitosis and decreases during S phase. Cdc10 controls the transcription of Cdc18, which accumulates during $\mathrm{G}_{1}$ phase (Kelly et al. 1993; Nishitani and Nurse 1995; Muzi Falconi et al. 1996; Baum et al. 1998). On S-phase entry, Cig2-Cdc2 phosphorylates $\mathrm{Cdc} 18$ and targets it for polyubiquitination by the SCF complex and degradation by the proteasome (Jallepalli et al. 1997, 1998; Kominami and Toda 1997; Kominami et al. 1998; Lopez-Girona et al. 1998; Wolf et al. 1999). Overproduction of wild-type Cdc18 alone induces rereplication (Nishitani and Nurse 1995; Muzi Falconi et al. 1996), and Cdc18 mutants lacking CDK consensus sites promote rereplication even more efficiently than the wild-type proteins (Jallepalli et al. 1997; Lopez-Girona et al. 1998). Expression of either of these mutants at a low level, however, is not sufficient to induce rereplication.

Cdt1 levels peak during late $M$ phase as a consequence of Cdc10-mediated transcriptional control, and protein levels decline during $\mathrm{S}$ phase as a result of proteolysis (Hofmann and 
Regulating DNA Replication in Eukarya

Beach 1994; Nishitani et al. 2000). Cdt1 degradation is mediated by CRL4-Cdt2 in a proliferating cell nuclear antigen (PCNA)-dependent manner (Hu and Xiong 2006; Ralph et al. 2006; Guarino et al. 2011), and chronic, low-level expression of both Cdt1 and Cdc18 is required to induce rereplication, suggesting that these two proteins are redundantly regulated (Gopalakrishnan et al. 2001).

Although fission yeast MCMs are constitutively nuclear (Yanow et al. 2001), their association with chromatin is cell-cycle-regulated. MCM complex assembly may also be regulated by the action of Mcb1 (MCM-binding protein) during the cell cycle (Ding and Forsburg 2011).

\section{CDK Control of Origin Firing}

Fission yeast Drcl and Sld3 are phosphorylated by S-phase CDK to promote formation of a ternary complex with Cut5 (Nakajima and Masukata 2002; Noguchi et al. 2002; Fukuura et al. 2011). The interaction recruits the complex to chromatin and may generate a platform for the formation of CMG complex. An Sld7 homolog in fission yeast has not been identified, and it is not clear if pre-IC factors are limiting for replication initiation in fission yeast or if they are targeted during checkpoint-dependent inhibition of late origin firing.

\section{REGULATION OF REPLICATION INITIATION IN METAZOANS}

Current knowledge on DNA replication in metazoans is based on studies performed primarily using three model systems: Xenopus egg extracts, Drosophila embryos and cell lines, and immortalized or cancerous mammalian cell lines. Advances in RNA interference (RNAi) and transgenesis have enabled genetic studies in cell culture or whole animals to elucidate regulation of these pathways. The details of origin recognition, origin licensing, and origin firing in these systems are summarized below. Plant DNA replication is discussed in detail elsewhere and is not included here.
Regulation of Origin Recognition in Metazoans

The replicon model proposed that initiation of DNA replication is determined by the binding of initiator proteins to a specific sequence of DNA at the origin of replication, termed the replicator (Jacob and Brenner 1963). Although this model holds true for prokaryotes and certain animal viruses, replicators in eukaryotes do not share a consensus sequence. Budding yeast ORC is the only known eukaryotic initiator that displays sequence specificity and binds to an 11bp autonomously replicating sequence element in vivo. However, in vitro, ORC from all species has intrinsic nonspecific DNA-binding activity and is capable of assembling pre-RCs onto diverse DNA sequences. Recruitment of a Gal4ORC fusion protein to a plasmid in cultured human cells converts the sequence adjacent to the Gal4-binding sites into an origin of replication and confers on it the property of onceper-cell-cycle replication (Takeda et al. 2005b). Thus, ORC binding to DNA is a primary requirement for any sequence to function as an origin. In vivo, ORC can be recruited by different sequence-specific binding proteins to chromosomal loci, for example, to telomeres by interaction with telomeric repeat-binding factor 2 (TRF2) (Tatsumi et al. 2008) or to the chorion gene cluster in Drosophila by Myb (Beall et al. 2002). Such a mechanism may also be used by viral genomes, for example, Epstein-Barr virus, that can recruit ORC to oriP in an Epstein-Barr nuclear antigen 1 (EBNA1)-dependent process (Dhar et al. 2001). There is increasing evidence that CpG islands and G-rich elements that can form G-quadruplexes influence origin recognition in vivo, and these are discussed in greater detail in a separate article (see article by Leonard and Méchali 2013, and references therein).

ORC binds to nucleosome-free regions of DNA in vivo (Sequeira-Mendes et al. 2009; Karnani et al. 2010; MacAlpine et al. 2010), and the nature of the chromatin around chromosomal ORC-binding sites influences origin licensing. Recruitment of ORC to different regions of the genome is necessary but not sufficient for pre-RC formation in vivo. For example, ORC 
K. Siddiqui et al.

binding to HP1 protein has no apparent role in origin determination; rather, it has been implicated in gene silencing and heterochromatin formation in many species (Pak et al. 1997; Shareef et al. 2001; Prasanth et al. 2010).

The retinoblastoma protein interacts with ORC in human and fly cells and negatively regulates DNA replication (Bosco et al. 2001; Mendoza-Maldonado et al. 2010), likely by recruiting histone deacetylase (HDAC) activities that generate repressive chromatin marks (Brehm et al. 1998). In support of this idea, stage 10 mosaic embryos derived from flies with mutations in $\mathrm{Rpd} 3 / \mathrm{Hdacl}$ are capable of replication across the entire genome in follicle cells, whereas this is restricted to the chorion genes in wild type (Aggarwal and Calvi 2004). Hdac11 has also been implicated as an inhibitor of origin licensing in mammalian cells (Wong et al. 2010).

To counter these deacetylating activities, ORC and Cdt1 recruit Hbo1, a histone acetyltransferase that binds to origins and acetylates surrounding chromatin during $\mathrm{G}_{1}$ to promote MCM loading (Miotto and Struhl 2008, 2010). Reduction of Hbol levels by small interfering RNA ( siRNA) treatment results in defective licensing and cell-cycle arrest. Increased acetylation and open chromatin is thus a common feature of most origins in both flies and human cells, as revealed by genome-wide mapping of origins in fly and human cell lines (MacAlpine et al. 2010; Mesner et al. 2011).

The Set8 histone methyltransferase also regulates origin licensing in human cells (Tardat et al. 2010). Targeting of Gal4-Set8 fusion protein to Gal4-binding sites on plasmid DNA in cultured cells is sufficient to promote MCM loading on adjacent sequences. Set 8 is a substrate of the CRL4-Cdt2-dependent degradation pathway in $\mathrm{S}$ phase (see below), and expression of a nondegradable Set8 protein results in rereplication in cultured human cells.

In rapidly dividing Xenopus embryos, DNA synthesis initiates at intervals of $\sim 10 \mathrm{~kb}$ in specific clusters (Blow et al. 2001). This allows a large amount of DNA to be replicated in a relatively short phase of $20 \mathrm{~min}$. Although exogenous AT-rich asymmetric sequences can outcompete replication complexes (Stanojcic et al.
2008), the nature of the DNA sequences at the initiation sites and the composition of histone modifications around the chromosomal initiation sites are unknown.

\section{Regulation of Origin Licensing in Metazoans}

ORC, Cdc6, and Cdt1 are essential for origin licensing in Xenopus egg extracts, Drosophila embryos, and cultured mammalian cells (Whittaker et al. 2000; Gillespie et al. 2001; Rialland et al. 2002; Mailand and Diffley 2005; Svitin and Chesnokov 2010; Gambus et al. 2011). Whereas fly ORC contains six subunits, similar to yeast, ORC in both vertebrates exists as a stable Orc1Orc5 assembly, with little or no Orc6 protein associated. This five-subunit complex is functional for MCM loading and sequence-independent replication of DNA substrates in a reconstituted system (Gillespie et al. 2001; Vashee et al. 2003). The absence of stoichiometric amounts of Orc6 subunit suggests that the mechanism of MCM loading in higher eukaryotes may be different from that in budding yeasts, where Orc6-Cdt1 interactions are critical for licensing (Chen et al. 2007; Chen and Bell 2011). Despite significant homology between metazoan Orc6 proteins (Dhar and Dutta 2000), human Orc6 interacts weakly with ORC, compared with its fly counterpart (Chesnokov et al. 1999; Vashee et al. 2003; Siddiqui and Stillman 2007). However, it is still required for DNA synthesis and may have evolved to perform other roles in origin recognition (Prasanth et al. 2002; Balasov et al. 2007; Thomae et al. 2008, 2011).

The function of ORC is restricted to $G_{1}$ phase by regulated ORC-DNA interactions across the cell cycle. Xenopus ORC is released from chromatin on licensing (Sun et al. 2002) and is only weakly associated with chromatin later in $\mathrm{G}_{2} / \mathrm{M}$ (Rowles et al. 1999). Mammalian ORC undergoes complex disassembly during $S$ phase as a consequence of ubiquitination of the Orc1 subunit. Ubiquitination results in Orc1 degradation in human cells (Mendez et al. 2002; Tatsumi et al. 2003) but, interestingly, not in hamster nuclei (Natale et al. 2000; Li and DePamphilis 2002). Human Orc1 ubiquitination 
is mediated by the $\mathrm{SCF}^{\mathrm{Skp} 2}$ ubiquitin ligase, which is known to act on phosphorylated substrates. Hence, it has been suggested that Orc1 degradation in human cells may be promoted by CDK phosphorylation, representing a CDKdependent mechanism to prevent relicensing. Drosophila cells uniquely regulate ORC and the APC/C ubiquitinates Orc1 for degradation after mitosis, in a situation similar to human Cdc6 (see below).

In metazoan cells ORC exhibits cell-cycledependent complex assembly. Human Orc4 protein requires an intact ATP-binding site for complex assembly in vitro, and this subunit does not associate stably with ORC across the cell cycle in vivo (Ranjan and Gossen 2006; Siddiqui and Stillman 2007). Immunofluorescence studies show that as cells proceed from $G_{1}$ to $\mathrm{G}_{2} / \mathrm{M}$, the chromatin-bound fraction of Orc2 and Orc3 decreases significantly (Prasanth et al. 2004; Siddiqui and Stillman 2007), and chromatin immunoprecipitation reveals a loss of ORC subunits at origins across the cell cycle (Gerhardt et al. 2006). This may also be promoted via CDK phosphorylation of Orc2, because a nonphosphorylatable Orc2 protein is found associated with origins during $\mathrm{G}_{2} / \mathrm{M}$ (Lee et al. 2012). It is therefore possible that assembly of ORC itself may be one mechanism to prevent unscheduled licensing.

Both Xenopus and human Cdc6 are phosphorylated by S-CDK, and ectopically expressed protein, on phosphorylation, is transported out of the nucleus into the cytoplasm (Petersen et al. 1999; Coverley et al. 2000; Pelizon et al. 2000; Delmolino et al. 2001). This is postulated to be a CDK-dependent control to prevent relicensing and may be redundant with other mechanisms, as expression of a nonphosphorylatable mutant of Cdc6 alone does not result in significant rereplication. It has been reported, however, that a significant fraction of native phosphorylated $\mathrm{Cdc} 6$ is retained on chromatin across $\mathrm{S}$ and $\mathrm{G}_{2} / \mathrm{M}$ in human cells (Coverley et al. 2000; Mendez and Stillman 2000; Alexandrow and Hamlin 2004) and may regulate entry into mitosis (ClayFarrace et al. 2003; Lau et al. 2006). At the end of mitosis, human Cdc6 is targeted for APC/ C-Cdh1-mediated degradation (Petersen et al.
2000) and degraded in early $\mathrm{G}_{1}$ phase. The consequence of having undegraded Cdc6 in cycling human cells is, at present, unknown. However, APC/C-mediated degradation may be a way of preventing unscheduled licensing in quiescent $\mathrm{G}_{0}$-phase cells. On cell-cycle reentry in cultured human cells, cyclin E-CDK2-mediated phosphorylation of Cdc6 blocks Cdh1 binding and stabilizes Cdc6 earlier than geminin, generating a window of opportunity to license origins (Duursma and Agami 2005; Mailand and Diffley 2005). We note that the APC/C-dependent degradation sequence in Drosophila Orc1 is bounded by a consensus CDK site, similar to the situation in human Cdc6. It is possible that the cyclin E-dependent association of Drosophila MCMs with chromatin may be via Orc1 stabilization (Su and O'Farrell 1997, 1998).

Metazoan Cdt1 is regulated by multiple pathways. Chromatin-bound Cdt1 is ubiquitinated during $\mathrm{S}$ phase by CRL4-Cdt2 ubiquitin ligase and targeted for degradation (Arias and Walter 2005; Li and Blow 2005). This pathway is dependent on its interaction with PCNA and is essential to prevent rereplication during $S$ phase (Arias and Walter 2006; Senga et al. 2006).

Additionally, a second $\mathrm{SCF}^{\text {Skp2 }}$-dependent pathway also promotes Cdt1 degradation throughout the cell cycle (Li et al. 2003; Nishitani et al. 2006). Although Cdt1 binds cyclin A in an RxL-dependent manner and is phosphorylated at consensus CDK sites ( $\mathrm{Li}$ et al. 2003; Sugimoto et al. 2004), mutations of these motifs do not result in significant rereplication (Takeda et al. 2005a; Nishitani et al. 2006), implying that the $\mathrm{SCF}^{\mathrm{Skp} 2}$-dependent proteolysis is a minor pathway. The CRL4-Cdt2 pathway is essential for Cdt1 degradation from fission yeasts to metazoans (Jin et al. 2006; Guarino et al. 2011). However, a role for the $\mathrm{SCF}^{\mathrm{Skp} 2}$ in Cdt1 degradation has only been shown in human cells, and this pathway may have arisen recently in evolution (Kim and Kipreos 2007).

Cdt 1 activity is also regulated by its interaction with geminin (Wohlschlegel et al. 2000; Tada et al. 2001), a protein discovered as an inhibitor ofDNA replication in Xenopus (McGarry and Kirschner 1998). Geminin is targeted for degradation by APC/C-Cdh1 and is hence 
K. Siddiqui et al.

absent from late mitosis until the end of $\mathrm{G}_{1}$, when licensing occurs (Nishitani et al. 2001). In Drosophila and mammalian cells, a major CDK-independent block to rereplication appears to require geminin, and reduction of protein levels by RNAi is sufficient to promote rereplication in many different cell lines (Quinn et al. 2001; Mihaylov et al. 2002; Melixetian et al. 2004; Zhu et al. 2004). Reduction of geminin levels by immunodepletion from Xenopus egg extracts or by injecting antisense oligonucleotides in embryos does not induce rereplication (McGarry and Kirschner 1998; McGarry 2002). However, expression of nondegradable Cdt 1 promotes more rereplication in a geminin-depleted extract, suggesting that both these pathways may be important for rereplication control in this species (Kerns et al. 2007).

Similar to yeast and Xenopus, mammalian MCMs are loaded onto the chromatin at the end of mitosis and are removed from chromatin as the cells pass through $S$ phase (Mendez and Stillman 2000). The MCM-BP protein is imported into the nucleus late in $S$ phase and interacts strongly with $\mathrm{Mcm} 7$ and may promote disassembly of the CMG complex (Nishiyama et al. 2011). Treatment of HeLa cells with siRNAs against MCM-BP results in $\mathrm{G}_{2} / \mathrm{M}$-arrested cells with MCMs persisting on chromatin for longer periods of time. The interaction between MCM-BP and MCMs appears to be replication-dependent, as nuclear MCM-BP does not stimulate disassembly of MCMs in aphidicolin-arrested cells.

\section{Regulation of Origin Firing in Metazoans}

Homologs of essential firing factors are known in metazoans, and CDK-dependent activation of replication origins has been verified, with roles for cyclin $\mathrm{E}$ in initiation of $\mathrm{S}$ phase and cyclin A during the elongation phase (Strausfeld et al. 1996; Mahbubani et al. 1997; Coverley et al. 2002). Cyclin $E$ is essential only in quiescent mouse fibroblasts that are reentering the cell cycle on growth factor stimulation (Geng et al. 2003) and may be redundant with cyclin A in most other cases (Kalaszczynska et al. 2009). DDK activity is similarly required for $G_{1} / S$ transition and DNA synthesis in mammalian cells and in Xenopus (Strausfeld et al. 1994; Jackson et al. 1995; Jiang et al. 1999; Walter 2000; Jares et al. 2004)

Despite highly divergent sequences to the budding yeast counterparts, the vertebrate homologs of Sld2 (RecQL4) and Sld3 (Treslin/ Ticrr) have been identified and are essential for replication initiation (Sangrithi et al. 2005; Kumagai et al. 2010; Sanchez-Pulido et al. 2010; Sansam et al. 2010; Boos et al. 2011). Analysis of TopBP1 (Dpb11 homolog) has revealed that it contains nine BRCT domains, referred to as BRCT0 to BRCTVIII (Makiniemi et al. 2001; Huo et al. 2010). Treslin binds to BRCTI/II domains of TopB1 in a CDK-dependent manner (Boos et al. 2011; Kumagai et al. 2011), similar to budding yeast Sld3-Dpb11 interaction. Based on homology between BRCTIII/IV of Dpb11 and BRCTIV/V of TopBP1, RecQL4 is expected to interact with TopBP1 via this domain. In contrast to the yeast proteins, the RecQL4-TopBP1 interaction is CDK-independent (Matsuno et al. 2006). Also, an amino-terminal fragment of TopBP1 containing BRCTIIII repeats is necessary and sufficient for Treslin function in Xenopus extracts (Kumagai et al. 2010). It is presently unclear if RecQL4 can interact with this amino-terminal fragment, perhaps via BRCTIII or other proteins that may be essential for initiation. Recently, GEMC1 and DUE-B have been identified as proteins that are phosphorylated in vivo that interact with Cdc45 and TopBP1 and have essential roles in vertebrate DNA synthesis (Balestrini et al. 2010; Chowdhury et al. 2010). It is unknown if these interactions are regulated across the cell cycle and what their specific roles are in activating the replicative helicase. RecQL4 may be a part of the active helicase in mammals, owing to its stable interaction with the CMG complex during $S$ phase (Xu et al. 2009). These observations suggest significant differences in the regulation of yeast and metazoan DNA replication, and further work is required to elucidate these mechanisms.

The Mcm 10 protein is essential during early steps of DNA synthesis. Recombinant Mcm10 interacts with single-stranded DNA (ssDNA) 
via an evolutionarily conserved oligonucleotide/oligosaccharide binding (OB)-fold domain. Mcm10 also recruits polymerase $\alpha$-primase complex (Zhu et al. 2007), which is required to initiate de novo replication. This recruitment is dependent on the And-1/Ctf4 protein. Based on its known interaction partners, it is possible that $\mathrm{Mcm} 10$ either mediates the initial melting reaction or stabilizes ssDNA generated during the initial unwinding reaction. If this is the case, then the activity of $\mathrm{Mcm} 10$ must be regulated because it is reported to bind chromatin independently of CDK or Cdc7 activities. (Van Hatten et al. 2002; Wohlschlegel et al. 2002). Mcm10 appears to be important for CMG complex assembly (Im et al. 2009) and may couple helicase to polymerase in replisomes in a Ctf4-dependent process (Zhu et al. 2007). Interestingly, Mcm10 stabilizes interactions between CMG and RecQL4 (Xu et al. 2009), and CDK phosphorylation of Mcm10 may be required to release RecQL4 during origin firing. These data raise the possibility that $\mathrm{Mcm} 10$ may be partly responsible for determining the temporal order of replication timing in metazoan cells, and the mechanisms underlying regulation of these interactions will be an important focus of future studies.

\section{CDK-Dependent Control of Replication Licensing}

CDK phosphorylation of Cdc6 plays a positive role in promoting licensing during $\mathrm{G}_{0} \rightarrow \mathrm{G}_{1}$ transition in mammalian cells (Mailand and Diffley 2005). Unlike in yeasts, it is unclear if CDK phosphorylation of the pre-RC proteins prevents rereplication during $\mathrm{S}$ phase in metazoans. Mammalian ORC, Cdc6, and Cdt1 all bind cyclin-CDKs directly and are substrates of CDKs in vitro (Saha et al. 1998; Petersen et al. 1999; Mendez et al. 2002; Sugimoto et al. 2004; Hemerly et al. 2009). However, studies using phosphorylation mutants of these proteins in vivo have not conclusively shown a role for such modifications in preventing rereplication during the cell cycle. Deletion of the aminoterminal region of Orc1 abolishes CDK phosphorylation in vitro but has no effect on ubiq- uitination in vivo (Mendez et al. 2002). Overexpression of Cdt1 mutants that are unable to bind cyclin or are not phosphorylatable shows more rereplication than wild-type protein ( $\mathrm{Ta}$ keda et al. 2005a), but because such mutants are degraded normally during $S$ phase, it is likely that they promote relicensing in other cell-cycle stages (Nishitani et al. 2006). The essential function of CDKs in preventing relicensing, therefore, appears to be during the $G_{2} / M$ phase of the cell cycle. Chemical inhibition of CDK activity during this period results in relicensing of chromatin even in the presence of geminin (Ballabeni et al. 2004; Vassilev et al. 2006). The essential targets of CDK for this $\mathrm{G}_{2} / \mathrm{M}$-specific inhibition are unknown; however, both Cdt1 and geminin are phosphorylated by CDKs in nocodazole-treated extracts and are potential candidates for this CDK-mediated regulation.

\section{CDK-Independent Control of Replication Licensing}

Metazoans have evolved CDK-independent pathways to prevent rereplication, and these are largely devoted to Cdt1 regulation. In contrast to yeast, deregulation of metazoan Cdt1 alone is sufficient to induce significant rereplication during $S$ phase (Melixetian et al. 2004; Zhu et al. 2004; Jin et al. 2006; Lovejoy et al. 2006; Sansam et al. 2006). Consequently, Cdt1 protein levels and activity are tightly regulated. This is achieved by a combination of Cdt2Ddb1-dependent degradation of chromatinbound Cdt1 during $S$ phase and interaction of Cdt1 with geminin during $S$ and $G_{2} / M$ phases. Degrading geminin during $S$ phase by premature activation of the APC/C leads to significant rereplication, and this can be suppressed by expression of a nondegradable mutant of geminin (Di Fiore and Pines 2007; Machida and Dutta 2007), highlighting the important role of this protein in maintaining genome ploidy.

Geminin inhibits licensing by blocking the Cdt1-MCM interaction (Wohlschlegel et al. 2000; Yanagi et al. 2002). Crystal structures have suggested a cell-cycle-dependent transition between two possible conformations of Cdt1geminin (Lee et al. 2004; De Marco et al. 2009). 
K. Siddiqui et al.

A heterotrimeric (Cdt1-geminin-geminin) state exposes the surface on Cdt1 that interacts with the MCMs and thus permits licensing. This alternates with a heterohexameric [Cdt1-(geminin $\left.)_{2}\right]_{2}$ state, in which the Cdt1-MCM interaction surface is hidden and is thus inhibitory to origin licensing. These observations are explained by a feedback model, whereby geminin functions cooperatively to inhibit licensing at multiple origins, therefore creating a critical threshold resulting in all-or-none inhibition of replication licensing (Ode et al. 2011). It is proposed that geminin and Cdt 1 interact at individual origins and the ability of these two proteins to oligomerize promotes interactions between proteins at adjacent origins, thereby propagating the inhibition of licensing and clustering origins into subnuclear foci. This clustering does not affect MCM complexes that are already loaded onto origins during $G_{1}$. Based on the expression profiles of these proteins, geminin serves its essential function in preventing rereplication primarily during $\mathrm{G}_{2} / \mathrm{M}$, when it not only inhibits Cdt1 degradation but also releases it for licensing in the subsequent $G_{1}$ (Ballabeni et al. 2004), much like Clb2-Cdc6 in budding yeasts.

\section{CONCLUDING REMARKS}

Although CDK-dependent pathways are primarily responsible for maintaining genome stability in budding yeasts, it is clear that CDKindependent mechanisms play a critical role in maintaining genome stability in multicellular organisms. Several cyclin subunits and CDK2 can be knocked out in mice (Sherr and Roberts 2004; Malumbres and Barbacid 2009), suggesting significant redundancy among the functions of cyclin-CDK complexes. Redundant mechanisms targeting ORC, Cdc6, and Cdt1-MCM inhibit rereplication in yeasts. In contrast, it appears that some mammalian cancer cell lines are particularly sensitive to Cdt1 deregulation alone, because RNAi-mediated silencing of geminin or Cdt2 is sufficient to induce significant rereplication in some cell lines but not others (Melixetian et al. 2004; Zhu et al. 2004; Jin et al. 2006; Lovejoy et al. 2006; Sansam et al. 2006). Although deregulating either ORC or
Cdc6 alone does not have a similar outcome, overexpression of these proteins can enhance the rereplication seen on Cdt1 overexpression (Vaziri et al. 2003; Sugimoto et al. 2009).

Deregulated licensing has emerged as a sensitive and early indicator of tumor development in human cancers (Freeman et al. 1999; Davies et al. 2002). Recent work has proposed that cancer cells may respond differently to licensing inhibition than primary cells (Shreeram et al. 2002; Zhu and DePamphilis 2009), and this could be exploited in designing therapies that selectively target cancer cells. The next few years will witness the identification of new replication factors (e.g., vertebrate Sld7) and lead to a better understanding as to how the divergence of proteins such as Orc6, Treslin, and RecQL4 confers unique properties to replication control in metazoan cells.

\section{ACKNOWLEDGMENTS}

We thank Anne Early for helpful comments on the manuscript. We apologize to authors whose work was not included or cited because of space constraints.

\section{REFERENCES}

${ }^{*}$ Reference is also in this collection.

Aggarwal BD, Calvi BR. 2004. Chromatin regulates origin activity in Drosophila follicle cells. Nature 430: 372-376.

Alexandrow MG, Hamlin JL. 2004. Cdc6 chromatin affinity is unaffected by serine- 54 phosphorylation, S-phase progression, and overexpression of cyclin A. Mol Cell Biol 24: 1614- 1627.

Ang XL, Wade Harper J. 2005. SCF-mediated protein degradation and cell cycle control. Oncogene 24: 2860-2870.

Aparicio T, Guillou E, Coloma J, Montoya G, Mendez J. 2009. The human GINS complex associates with Cdc45 and MCM and is essential for DNA replication. Nucleic Acids Res 37: 2087-2095.

Arias EE, Walter JC. 2005. Replication-dependent destruction of Cdt1 limits DNA replication to a single round per cell cycle in Xenopus egg extracts. Genes Dev 19: 114-126.

Arias EE, Walter JC. 2006. PCNA functions as a molecular platform to trigger Cdt1 destruction and prevent re-replication. Nat Cell Biol 8: 84-90.

Balasov M, Huijbregts RP, Chesnokov I. 2007. Role of the Orc6 protein in origin recognition complex-dependent DNA binding and replication in Drosophila melanogaster. Mol Cell Biol 27: 3143-3153. 
Balestrini A, Cosentino C, Errico A, Garner E, Costanzo V. 2010. GEMC1 is a TopBP1-interacting protein required for chromosomal DNA replication. Nat Cell Biol 12: 484-491.

Ballabeni A, Melixetian M, Zamponi R, Masiero L, Marinoni F, Helin K. 2004. Human Geminin promotes pre-RC formation and DNA replication by stabilizing CDT1 in mitosis. EMBO J 23: 3122-3132.

Baum B, Nishitani H, Yanow S, Nurse P. 1998. Cdc18 transcription and proteolysis couple $S$ phase to passage through mitosis. EMBO J 17: 5689-5698.

Beall EL, Manak JR, Zhou S, Bell M, Lipsick JS, Botchan MR. 2002. Role for a Drosophila Myb-containing protein complex in site-specific DNA replication. Nature 420: 833-837.

Bell SP, Stillman B. 1992. ATP-dependent recognition of eukaryotic origins of DNA replication by a multiprotein complex. Nature 357: 128-134.

Blow JJ, Gillespie PJ, Francis D, Jackson DA. 2001. Replication origins in Xenopus egg extract are 5-15 kilobases apart and are activated in clusters that fire at different times. J Cell Biol 152: 15-25.

Blow JJ, Ge XQ, Jackson DA. 2011. How dormant origins promote complete genome replication. Trends Biochem Sci 36: 405-414.

Boos D, Sanchez-Pulido L, Rappas M, Pearl LH, Oliver AW, Ponting CP, Diffley JF. 2011. Regulation of DNA replication through Sld3-Dpb11 interaction is conserved from yeast to humans. Curr Biol 21: 1152-1157.

Bosco G, Du W, Orr-Weaver TL. 2001. DNA replication control through interaction of E2F-RB and the origin recognition complex. Nat Cell Biol 3: 289-295.

Bousset K, Diffley JF. 1998. The Cdc7 protein kinase is required for origin firing during $S$ phase. Genes Dev 12: 480-490.

Braun KA, Breeden LL. 2007. Nascent transcription of MCM2-7 is important for nuclear localization of the minichromosome maintenance complex in $\mathrm{G}_{1}$. Mol Biol Cell 18: 1447-1456.

Brehm A, Miska EA, McCance DJ, Reid JL, Bannister AJ, Kouzarides T. 1998. Retinoblastoma protein recruits histone deacetylase to repress transcription. Nature 391: 597-601.

Calzada A, Sacristan M, Sanchez E, Bueno A. 2001. Cdc6 cooperates with Sicl and Hctl to inactivate mitotic cyclin-dependent kinases. Nature 412: 355-358.

Chen S, Bell SP. 2011. CDK prevents Mcm2-7 helicase loading by inhibiting Cdt1 interaction with Orc6. Genes Dev 25: 363-372.

Chen S, de Vries MA, Bell SP. 2007. Orc6 is required for dynamic recruitment of Cdt1 during repeated $\mathrm{Mcm} 2-7$ loading. Genes Dev 21: 2897-2907.

Cheng IH, Roberts LA, Tye BK. 2002. Mcm3 is polyubiquitinated during mitosis before establishment of the prereplication complex. J Biol Chem 277: 41706-41714.

Chesnokov I, Gossen M, Remus D, Botchan M. 1999. Assembly of functionally active Drosophila origin recognition complex from recombinant proteins. Genes Dev 13: 1289-1296.

Chowdhury A, Liu G, Kemp M, Chen X, Katrangi N, Myers S, Ghosh M, Yao J, Gao Y, Bubulya P, et al. 2010.
The DNA unwinding element binding protein DUE-B interacts with $\mathrm{Cdc} 45$ in preinitiation complex formation. Mol Cell Biol 30: 1495-1507.

Chuang RY, Kelly TJ. 1999. The fission yeast homologue of Orc4p binds to replication origin DNA via multiple AThooks. Proc Natl Acad Sci 96: 2656-2661.

Clay-Farrace L, Pelizon C, Santamaria D, Pines J, Laskey RA. 2003. Human replication protein Cdc6 prevents mitosis through a checkpoint mechanism that implicates Chk1. EMBO J 22: 704-712.

Costanzo M, Nishikawa JL, Tang X, Millman JS, Schub O, Breitkreuz K, Dewar D, Rupes I, Andrews B, Tyers M. 2004. CDK activity antagonizes Whi5, an inhibitor of G1/S transcription in yeast. Cell 117: 899-913.

Coudreuse D, Nurse P. 2010. Driving the cell cycle with a minimal CDK control network. Nature 468: 1074-1079.

Coverley D, Pelizon C, Trewick S, Laskey RA. 2000. Chromatin-bound Cdc6 persists in $S$ and $\mathrm{G}_{2}$ phases in human cells, while soluble Cdc6 is destroyed in a cyclin A-cdk2 dependent process. J Cell Sci 113: 1929-1938.

Coverley D, Laman H, Laskey RA. 2002. Distinct roles for cyclins $\mathrm{E}$ and A during DNA replication complex assembly and activation. Nat Cell Biol 4: 523-528.

Davies RJ, Freeman A, Morris LS, Bingham S, Dilworth S, Scott I, Laskey RA, Miller R, Coleman N. 2002. Analysis of minichromosome maintenance proteins as a novel method for detection of colorectal cancer in stool. Lancet 359: 1917-1919.

de Bruin RA, McDonald WH, Kalashnikova TI, Yates J III, Wittenberg C. 2004. Cln3 activates G1-specific transcription via phosphorylation of the SBF bound repressor Whi5. Cell 117: 887-898.

Delmolino LM, Saha P, Dutta A. 2001. Multiple mechanisms regulate subcellular localization of human CDC6. J Biol Chem 276: 26947-26954.

De Marco V, Gillespie PJ, Li A, Karantzelis N, Christodoulou E, Klompmaker R, van Gerwen S, Fish A, Petoukhov MV, Iliou MS, et al. 2009. Quaternary structure of the human Cdt1-Geminin complex regulates DNA replication licensing. Proc Natl Acad Sci 106: 19807-19812.

Dhar SK, Dutta A. 2000. Identification and characterization of the human ORC6 homolog. J Biol Chem 275: 3498334988.

Dhar SK, Yoshida K, Machida Y, Khaira P, Chaudhuri B, Wohlschlegel JA, Leffak M, Yates J, Dutta A. 2001. Replication from oriP of Epstein-Barr virus requires human ORC and is inhibited by geminin. Cell 106: 287-296.

Diffley JF. 2011. Quality control in the initiation of eukaryotic DNA replication. Philos Trans R Soc Lond B Biol Sci 366: $3545-3553$.

Di Fiore B, Pines J. 2007. Emil is needed to couple DNA replication with mitosis but does not regulate activation of the mitotic APC/C. J Cell Biol 177: 425-437.

Ding L, Forsburg SL. 2011. Schizosaccharomyces pombe minichromosome maintenance-binding protein (MCMBP) antagonizes MCM helicase. J Biol Chem 286: 32918 32930.

Dirick L, Bohm T, Nasmyth K. 1995. Roles and regulation of $\mathrm{Cln}-\mathrm{Cdc} 28$ kinases at the start of the cell cycle of Saccharomyces cerevisiae. EMBO J 14: 4803-4813. 
K. Siddiqui et al.

Dolan WP, Sherman DA, Forsburg SL. 2004. Schizosaccharomyces pombe replication protein Cdc45/Sna41 requires Hsk1/Cdc7 and Rad4/Cut5 for chromatin binding. Chromosoma 113: 145-156.

Donovan JD, Toyn JH, Johnson AL, Johnston LH. 1994 $\mathrm{P} 40^{S D B 25}$, a putative CDK inhibitor, has a role in the $\mathrm{M} / \mathrm{G}_{1}$ transition in Saccharomyces cerevisiae. Genes Dev 8: $1640-1653$.

Donovan S, Harwood J, Drury LS, Diffley JF. 1997. Cdc6pdependent loading of $\mathrm{Mcm}$ proteins onto pre-replicative chromatin in budding yeast. Proc Natl Acad Sci 94: 5611-5616.

Drury LS, Perkins G, Diffley JF. 1997. The Cdc4/34/53 pathway targets Cdc6p for proteolysis in budding yeast. EMBO J 16: 5966-5976.

Drury LS, Perkins G, Diffley JF. 2000. The cyclin-dependent kinase $\mathrm{Cdc} 28 \mathrm{p}$ regulates distinct modes of Cdc6p proteolysis during the budding yeast cell cycle. Curr Biol 10: 231-240.

Duursma A, Agami R. 2005. p53-dependent regulation of Cdc6 protein stability controls cellular proliferation. $\mathrm{Mol}$ Cell Biol 25: 6937-6947.

Elsasser S, Lou F, Wang B, Campbell JL, Jong A. 1996. Interaction between yeast Cdc6 protein and B-type cyclin/ Cdc28 kinases. Mol Biol Cell 7: 1723-1735.

Elsasser S, Chi Y, Yang P, Campbell JL. 1999. Phosphorylation controls timing of Cdc6p destruction: A biochemical analysis. Mol Biol Cell 10: 3263-3277.

Eser U, Falleur-Fettig M, Johnson A, Skotheim JM. 2011. Commitment to a cellular transition precedes genomewide transcriptional change. Mol Cell 43: 515-527.

Evrin C, Clarke P, Zech J, Lurz R, Sun J, Uhle S, Li H, Stillman B, Speck C. 2009. A double-hexameric MCM27 complex is loaded onto origin DNA during licensing of eukaryotic DNA replication. Proc Natl Acad Sci 106: 20240-20245.

Feldman RM, Correll CC, Kaplan KB, Deshaies RJ. 1997. A complex of Cdc4p, Skp1p, and Cdc53p/cullin catalyzes ubiquitination of the phosphorylated CDK inhibitor Siclp. Cell 91: 221-230.

Ferreira MF, Santocanale C, Drury LS, Diffley JF. 2000. Dbf4p, an essential S phase-promoting factor, is targeted for degradation by the anaphase-promoting complex. Mol Cell Biol 20: 242-248.

Francis LI, Randell JC, Takara TJ, Uchima L, Bell SP. 2009. Incorporation into the prereplicative complex activates the $\mathrm{Mcm} 2-7$ helicase for Cdc7-Dbf4 phosphorylation. Genes Dev 23: 643-654.

Freeman A, Morris LS, Mills AD, Stoeber K, Laskey RA, Williams GH, Coleman N. 1999. Minichromosome maintenance proteins as biological markers of dysplasia and malignancy. Clin Cancer Res 5: 2121-2132.

Fukuura M, Nagao K, Obuse C, Takahashi TS, Nakagawa T, Masukata H. 2011. CDK promotes interactions of Sld3 and Drc1 with Cut5 for initiation of DNA replication in fission yeast. Mol Biol Cell 22: 2620-2633.

Gambus A, Khoudoli GA, Jones RC, Blow JJ. 2011. MCM2-7 form double hexamers at licensed origins in Xenopus egg extract. J Biol Chem 286: 11855-11864.

Geng Y, Yu Q, Sicinska E, Das M, Schneider JE, Bhattacharya S, Rideout WM, Bronson RT, Gardner $\mathrm{H}$
Sicinski P. 2003. Cyclin E ablation in the mouse. Cell 114: $431-443$.

Gerhardt J, Jafar S, Spindler MP, Ott E, Schepers A. 2006. Identification of new human origins of DNA replication by an origin-trapping assay. Mol Cell Biol 26: 7731-7746.

Gillespie PJ, Li A, Blow JJ. 2001. Reconstitution of licensed replication origins on Xenopus sperm nuclei using purified proteins. BMC Biochem 2: 15.

Gopalakrishnan V, Simancek P, Houchens C, Snaith HA, Frattini MG, Sazer S, Kelly TJ. 2001. Redundant control of rereplication in fission yeast. Proc Natl Acad Sci 98: 13114-13119.

Grallert B, Nurse P. 1996. The ORC1 homolog orp1 in fission yeast plays a key role in regulating onset of $S$ phase. Genes Dev 10: 2644-2654.

Green BM, Morreale RJ, Ozaydin B, Derisi JL, Li JJ. 2006. Genome-wide mapping of DNA synthesis in Saccharomyces cerevisiae reveals that mechanisms preventing reinitiation of DNA replication are not redundant. Mol Biol Cell 17: 2401-2414.

Green BM, Finn KJ, Li JJ. 2010. Loss of DNA replication control is a potent inducer of gene amplification. Science 329: 943-946.

Gregan J, Lindner K, Brimage L, Franklin R, Namdar M, Hart EA, Aves SJ, Kearsey SE. 2003. Fission yeast $\mathrm{Cdc} 23 / \mathrm{Mcm} 10$ functions after pre-replicative complex formation to promote $\mathrm{Cdc} 45$ chromatin binding. $\mathrm{Mol}$ Biol Cell 14: 3876-3887.

Guarino E, Shepherd ME, Salguero I, Hua H, Deegan RS, Kearsey SE. 2011. Cdt1 proteolysis is promoted by dua PIP degrons and is modulated by PCNA ubiquitylation. Nucleic Acids Res 39: 5978-5990.

Hardy CF, Dryga O, Seematter S, Pahl PM, Sclafani RA. 1997. $m c m 5 / c d c 46-b o b 1$ bypasses the requirement for the S phase activator Cdc7p. Proc Natl Acad Sci 94: 3151-3155.

Harper JW, Elledge SJ. 2007. The DNA damage response: Ten years after. Mol Cell 28: 739-745.

Hayashi M, Katou Y, Itoh T, Tazumi A, Yamada Y, Takahashi T, Nakagawa T, Shirahige K, Masukata $\mathrm{H}$. 2007. Genome-wide localization of pre-RC sites and identification of replication origins in fission yeast. EMBO J 26: 1327-1339.

Hemerly AS, Prasanth SG, Siddiqui K, Stillman B. 2009. Orcl controls centriole and centrosome copy number in human cells. Science 323: 789-793.

Hofmann JF, Beach D. 1994. $c d t 1$ is an essential target of the Cdc10/Sct1 transcription factor: Requirement for DNA replication and inhibition of mitosis. EMBO J 13: 425434.

Hu J, Xiong Y. 2006. An evolutionarily conserved function of proliferating cell nuclear antigen for Cdt 1 degradation by the Cul4-Ddb1 ubiquitin ligase in response to DNA damage. J Biol Chem 281: 3753-3756.

Huo YG, Bai L, Xu M, Jiang T. 2010. Crystal structure of the $\mathrm{N}$-terminal region of human topoisomerase II $\beta$ binding protein 1. Biochem Biophys Res Commun 401: 401-405.

Im JS, Ki SH, Farina A, Jung DS, Hurwitz J, Lee JK. 2009. Assembly of the Cdc45-Mcm2-7-GINS complex in human cells requires the Ctf4/And-1, RecQL4, and Mcm10 proteins. Proc Natl Acad Sci 106: 15628-15632. 
Jackson PK, Chevalier S, Philippe M, Kirschner MW. 1995. Early events in DNA replication require cyclin $\mathrm{E}$ and are blocked by $\mathrm{p}_{21}^{\mathrm{CIP} 1}$. J Cell Biol 130: 755-769.

Jacob F, Brenner S. 1963. [On the regulation of DNA synthesis in bacteria: The hypothesis of the replicon]. $C R$ Hebd Seances Acad Sci 256: 298-300.

Jallepalli PV, Brown GW, Muzi-Falconi M, Tien D, Kelly TJ. 1997. Regulation of the replication initiator protein p $65^{\text {cdc18 }}$ by CDK phosphorylation. Genes Dev 11: 2767-2779.

Jallepalli PV, Tien D, Kelly TJ. 1998. sud1 ${ }^{+}$targets cyclindependent kinase-phosphorylated $\mathrm{Cdcl} 8$ and Ruml proteins for degradation and stops unwanted diploidization in fission yeast. Proc Natl Acad Sci 95: 8159-8164.

Jares P, Luciani MG, Blow JJ. 2004. A Xenopus Dbf4 homolog is required for $\mathrm{Cdc7}$ chromatin binding and DNA replication. BMC Mol Biol 5: 5 .

Jaspersen SL, Charles JF, Morgan DO. 1999. Inhibitory phosphorylation of the APC regulator Hctl is controlled by the kinase Cdc28 and the phosphatase Cdc14. Curr Biol 9: 227-236.

Jiang W, McDonald D, Hope TJ, Hunter T. 1999. Mammalian Cdc7-Dbf4 protein kinase complex is essential for initiation of DNA replication. EMBO J 18: 5703-5713.

Jin J, Arias EE, Chen J, Harper JW, Walter JC. 2006. A family of diverse Cul4-Ddb1-interacting proteins includes Cdt2, which is required for $\mathrm{S}$ phase destruction of the replication factor Cdt1. Mol Cell 23: 709-721.

Kalaszczynska I, Geng Y, Iino T, Mizuno S, Choi Y, Kondratiuk I, Silver DP, Wolgemuth DJ, Akashi K, Sicinski P. 2009. Cyclin A is redundant in fibroblasts but essential in hematopoietic and embryonic stem cells. Cell 138: $352-365$.

Kamimura Y, Masumoto H, Sugino A, Araki H. 1998. Sld2, which interacts with Dpb11 in Saccharomyces cerevisiae, is required for chromosomal DNA replication. Mol Cell Biol 18: 6102-6109.

Kamimura Y, Tak YS, Sugino A, Araki H. 2001. Sld3, which interacts with Cdc45 (Sld4), functions for chromosomal DNA replication in Saccharomyces cerevisiae. EMBO J 20: 2097-2107.

Karnani N, Taylor CM, Malhotra A, Dutta A. 2010. Genomic study of replication initiation in human chromosomes reveals the influence of transcription regulation and chromatin structure on origin selection. Mol Biol Cell 21: 393-404.

Kawabata T, Luebben SW, Yamaguchi S, Ilves I, Matise I, Buske T, Botchan MR, Shima N. 2011. Stalled fork rescue via dormant replication origins in unchallenged $\mathrm{S}$ phase promotes proper chromosome segregation and tumor suppression. Mol Cell 41: 543-553.

Kelly TJ, Martin GS, Forsburg SL, Stephen RJ, Russo A, Nurse P. 1993. The fission yeast $c d c 18^{+}$gene product couples S phase to START and mitosis. Cell 74: $371-382$.

Kerns SL, Torke SJ, Benjamin JM, McGarry TJ. 2007. Geminin prevents rereplication during Xenopus development. J Biol Chem 282: 5514-5521.

Kim Y, Kipreos ET. 2007. Cdt1 degradation to prevent DNA re-replication: Conserved and non-conserved pathways. Cell Div 2: 18.
Klemm RD, Bell SP. 2001. ATP bound to the origin recognition complex is important for preRC formation. Proc Natl Acad Sci 98: 8361-8367.

Knapp D, Bhoite L, Stillman DJ, Nasmyth K. 1996. The transcription factor Swi5 regulates expression of the cyclin kinase inhibitor p40 ${ }^{\text {SIC1. }}$. Mol Cell Biol 16: 57015707.

Koch C, Moll T, Neuberg M, Ahorn H, Nasmyth K. 1993. A role for the transcription factors $\mathrm{Mbp} 1$ and Swi4 in progression from G1 to S phase. Science 261: 1551-1557.

Koivomagi M, Valk E, Venta R, Iofik A, Lepiku M, Balog ER, Rubin SM, Morgan DO, Loog M. 2011a. Cascades of multisite phosphorylation control Sicl destruction at the onset of S phase. Nature 480: 128-131.

Koivomagi M, Valk E, Venta R, Iofik A, Lepiku M, Morgan DO, Loog M. 2011b. Dynamics of Cdk1 substrate specificity during the cell cycle. Mol Cell 42: $610-623$.

Kominami K, Toda T. 1997. Fission yeast WD-repeat protein Pop1 regulates genome ploidy through ubiquitin-proteasome-mediated degradation of the $\mathrm{CDK}$ inhibitor Rum1 and the S-phase initiator Cdc18. Genes Dev 11: $1548-1560$.

Kominami K, Ochotorena I, Toda T. 1998. Two F-box/WDrepeat proteins Pop1 and Pop2 form hetero- and homocomplexes together with cullin- 1 in the fission yeast SCF (Skp1-Cullin-1-F-box) ubiquitin ligase. Genes Cells 3: 721-735.

Kong D, DePamphilis ML. 2001. Site-specific DNA binding of the Schizosaccharomyces pombe origin recognition complex is determined by the Orc4 subunit. Mol Cell Biol 21: 8095-8103.

Kraft C, Herzog F, Gieffers C, Mechtler K, Hagting A, Pines J, Peters JM. 2003. Mitotic regulation of the human anaphase-promoting complex by phosphorylation. $E M B O J$ 22: 6598-6609.

Kumagai A, Shevchenko A, Shevchenko A, Dunphy WG. 2010. Treslin collaborates with TopBP1 in triggering the initiation of DNA replication. Cell 140: 349-359.

Kumagai A, Shevchenko A, Shevchenko A, Dunphy WG. 2011. Direct regulation of Treslin by cyclin-dependent kinase is essential for the onset of DNA replication. $J$ Cell Biol 193: 995-1007.

Kunkel TA, Burgers PM. 2008. Dividing the workload at a eukaryotic replication fork. Trends Cell Biol 18: 521-527.

Labib K, Diffley JF, Kearsey SE. 1999. G1-phase and B-type cyclins exclude the DNA-replication factor $\mathrm{Mcm} 4$ from the nucleus. Nat Cell Biol 1: 415-422.

Lau E, Zhu C, Abraham RT, Jiang W. 2006. The functional role of Cdc6 in S-G2/M in mammalian cells. EMBO Rep 7: 425-430.

Lee JK, Moon KY, Jiang Y, Hurwitz J. 2001. The Schizosaccharomyces pombe origin recognition complex interacts with multiple AT-rich regions of the replication origin DNA by means of the AT-hook domains of the spOrc4 protein. Proc Natl Acad Sci 98: 13589-13594.

Lee C, Hong B, Choi JM, Kim Y, Watanabe S, Ishimi Y, Enomoto T, Tada S, Kim Y, Cho Y. 2004. Structural basis for inhibition of the replication licensing factor Cdt1 by geminin. Nature 430: 913-917. 
K. Siddiqui et al.

Lee KY, Bang SW, Yoon SW, Lee SH, Yoon JB, Hwang DS 2012. Phosphorylation of ORC2 protein dissociates origin recognition complex from chromatin and replication origins. J Biol Chem 287: 11891-11898.

Lengauer C, Kinzler KW, Vogelstein B. 1998. Genetic instabilities in human cancers. Nature 396: 643-649.

* Leonard AC, Méchali M. 2013. DNA replication origins. Cold Spring Harb Perspect Biol doi: 10.1101/cshperspect.a010116.

Li A, Blow JJ. 2005. Cdt1 downregulation by proteolysis and geminin inhibition prevents DNA re-replication in Xenopus. EMBO J 24: 395-404.

Li CJ, DePamphilis ML. 2002. Mammalian Orc1 protein is selectively released from chromatin and ubiquitinated during the S-to-M transition in the cell division cycle. Mol Cell Biol 22: 105-116.

Li X, Zhao Q, Liao R, Sun P, Wu X. 2003. The $S_{C F}{ }^{\text {Skp2 }}$ ubiquitin ligase complex interacts with the human replication licensing factor Cdt 1 and regulates Cdt 1 degradation. J Biol Chem 278: 30854-30858.

Liku ME, Nguyen VQ, Rosales AW, Irie K, Li JJ. 2005. CDK phosphorylation of a novel NLS-NES module distributed between two subunits of the $\mathrm{Mcm} 2-7$ complex prevents chromosomal rereplication. Mol Biol Cell 16: 5026-5039.

Lopez-Girona A, Mondesert O, Leatherwood J, Russell P. 1998. Negative regulation of Cdc18 DNA replication protein by Cdc2. Mol Biol Cell 9: 63-73.

Lovejoy CA, Lock K, Yenamandra A, Cortez D. 2006. DDB1 maintains genome integrity through regulation of Cdt1. Mol Cell Biol 26: 7977-7990.

Lowndes NF, Johnson AL, Breeden L, Johnston LH. 1992. SWI6 protein is required for transcription of the periodically expressed DNA synthesis genes in budding yeast. Nature 357: 505-508.

MacAlpine HK, Gordan R, Powell SK, Hartemink AJ, MacAlpine DM. 2010. Drosophila ORC localizes to open chromatin and marks sites of cohesin complex loading. Genome Res 20: 201-211.

Machida YJ, Dutta A. 2007. The APC/C inhibitor, Emil, is essential for prevention of rereplication. Genes Dev 21: 184-194.

Mahbubani HM, Chong JP, Chevalier S, Thommes P, Blow JJ. 1997. Cell cycle regulation of the replication licensing system: Involvement of a Cdk-dependent inhibitor. J Cell Biol 136: 125-135.

Mailand N, Diffley JF. 2005. CDKs promote DNA replication origin licensing in human cells by protecting Cdc6 from APC/C-dependent proteolysis. Cell 122: 915-926.

Maiorano D, Van Assendelft GB, Kearsey SE. 1996. Fission yeast $\operatorname{cdc} 21$, a member of the MCM protein family, is required for onset of $S$ phase and is located in the nucleus throughout the cell cycle. $E M B O J$ 15: 861-872.

Makiniemi M, Hillukkala T, Tuusa J, Reini K, Vaara M, Huang D, Pospiech H, Majuri I, Westerling T, Makela TP, et al. 2001. BRCT domain-containing protein TopBP1 functions in DNA replication and damage response. J Biol Chem 276: 30399-30406.

Malumbres M, Barbacid M. 2009. Cell cycle, CDKs and cancer: A changing paradigm. Nat Rev Cancer 9: 153166.
Masumoto H, Muramatsu S, Kamimura Y, Araki H. 2002. S-Cdk-dependent phosphorylation of Sld2 essential for chromosomal DNA replication in budding yeast. Nature 415: 651-655.

Matsuno K, Kumano M, Kubota Y, Hashimoto Y, Takisawa H. 2006. The N-terminal noncatalytic region of Xenopus RecQ4 is required for chromatin binding of DNA polymerase $\alpha$ in the initiation of DNA replication. Mol Cell Biol 26: 4843-4852.

McGarry TJ. 2002. Geminin deficiency causes a Chk1dependent G2 arrest in Xenopus. Mol Biol Cell 13: 3662-3671.

McGarry TJ, Kirschner MW. 1998. Geminin, an inhibitor of DNA replication, is degraded during mitosis. Cell 93: 1043-1053.

Melixetian M, Ballabeni A, Masiero L, Gasparini P, Zamponi R, Bartek J, Lukas J, Helin K. 2004. Loss of Geminin induces rereplication in the presence of functional p53. J Cell Biol 165: 473-482.

Mendez J, Stillman B. 2000. Chromatin association of human origin recognition complex, Cdc6, and minichromosome maintenance proteins during the cell cycle: Assembly of prereplication complexes in late mitosis. $\mathrm{Mol}$ Cell Biol 20: 8602-8612.

Mendez J, Zou-Yang XH, Kim SY, Hidaka M, Tansey WP, Stillman B. 2002. Human origin recognition complex large subunit is degraded by ubiquitin-mediated proteolysis after initiation of DNA replication. Mol Cell 9: 481-491.

Mendoza-Maldonado R, Paolinelli R, Galbiati L, Giadrossi S, Giacca M. 2010. Interaction of the retinoblastoma protein with Orcl and its recruitment to human origins of DNA replication. PloS ONE 5: e13720.

Mesner LD, Valsakumar V, Karnani N, Dutta A, Hamlin JL, Bekiranov S. 2011. Bubble-chip analysis of human origin distributions demonstrates on a genomic scale significant clustering into zones and significant association with transcription. Genome Res 21: 377-389.

Mihaylov IS, Kondo T, Jones L, Ryzhikov S, Tanaka J, Zheng J, Higa LA, Minamino N, Cooley L, Zhang H. 2002. Control of DNA replication and chromosome ploidy by geminin and cyclin A. Mol Cell Biol 22: 1868-1880

Mimura S, Seki T, Tanaka S, Diffley JFX. 2004. Phosphorylation-dependent binding of mitotic cyclins to Cdc6 contributes to DNA replication control. Nature 431: 1118 1123 .

Miotto B, Struhl K. 2008. HBO1 histone acetylase is a coactivator of the replication licensing factor Cdt1. Genes Dev 22: 2633-2638.

Miotto B, Struhl K. 2010. HBO1 histone acetylase activity is essential for DNA replication licensing and inhibited by Geminin. Mol Cell 37: 57-66.

Moyer SE, Lewis PW, Botchan MR. 2006. Isolation of the Cdc45/Mcm2-7/GINS (CMG) complex, a candidate for the eukaryotic DNA replication fork helicase. Proc Natl Acad Sci 103: 10236-10241.

Muramatsu S, Hirai K, Tak YS, Kamimura Y, Araki H. 2010. CDK-dependent complex formation between replication proteins Dpb11, Sld2, Pol $\varepsilon$, and GINS in budding yeast. Genes Dev 24: 602-612. 
Muzi Falconi M, Brown GW, Kelly TJ. 1996. $c d c 18^{+}$regulates initiation of DNA replication in Schizosaccharomyces pombe. Proc Natl Acad Sci 93: 1566-1570.

Nakajima R, Masukata H. 2002. SpSld3 is required for loading and maintenance of SpCdc45 on chromatin in DNA replication in fission yeast. Mol Biol Cell 13: 1462-1472.

Nakayama KI, Nakayama K. 2006. Ubiquitin ligases: Cellcycle control and cancer. Nat Rev Cancer 6: 369-381.

Nasmyth K, Dirick L. 1991. The role of SWI4 and SWI6 in the activity of G1 cyclins in yeast. Cell 66: 995-1013.

Natale DA, Li CJ, Sun WH, DePamphilis ML. 2000. Selective instability of Orcl protein accounts for the absence of functional origin recognition complexes during the $\mathrm{M}-$ $\mathrm{G}_{1}$ transition in mammals. EMBO J 19: 2728-2738.

Nguyen VQ, Co C, Irie K, Li JJ. 2000. Clb/Cdc28 kinases promote nuclear export of the replication initiator proteins Mcm2-7. Curr Biol 10: 195-205.

Nguyen VQ, Co C, Li JJ. 2001. Cyclin-dependent kinases prevent DNA re-replication through multiple mechanisms. Nature 411: 1068-1073.

Nishitani H, Nurse P. 1995. p65 $5^{\text {cdc18 }}$ plays a major role controlling the initiation of DNA replication in fission yeast. Cell 83: 397-405.

Nishitani H, Lygerou Z, Nishimoto T, Nurse P. 2000. The Cdt1 protein is required to license DNA for replication in fission yeast. Nature 404: 625-628.

Nishitani H, Taraviras S, Lygerou Z, Nishimoto T. 2001. The human licensing factor for DNA replication Cdt1 accumulates in $\mathrm{G}_{1}$ and is destabilized after initiation of $\mathrm{S}$ phase. J Biol Chem 276: 44905-44911.

Nishitani H, Sugimoto N, Roukos V, Nakanishi Y, Saijo M, Obuse C, Tsurimoto T, Nakayama KI, Nakayama K, Fujita M, et al. 2006. Two E3 ubiquitin ligases, SCFSkp2 and DDB1-Cul4, target human Cdt1 for proteolysis. $E M B O$ J 25: 1126-1136.

Nishiyama A, Frappier L, Mechali M. 2011. MCM-BP regulates unloading of the MCM2-7 helicase in late S phase. Genes Dev 25: 165-175.

Noguchi E, Shanahan P, Noguchi C, Russell P. 2002. CDK phosphorylation of Drcl regulates DNA replication in fission yeast. Curr Biol 12: 599-605.

Nugroho TT, Mendenhall MD. 1994. An inhibitor of yeast cyclin-dependent protein kinase plays an important role in ensuring the genomic integrity of daughter cells. Mol Cell Biol 14: 3320-3328.

Ode KL, Fujimoto K, Kubota Y, Takisawa H. 2011. Interorigin cooperativity of geminin action establishes an allor-none switch for replication origin licensing. Genes Cells 16: 380-396.

Ogawa Y, Takahashi T, Masukata H. 1999. Association of fission yeast Orp1 and Mcm6 proteins with chromosomal replication origins. Mol Cell Biol 19: 7228-7236.

Oshiro G, Owens JC, Shellman Y, Sclafani RA, Li JJ. 1999. Cell cycle control of Cdc7p kinase activity through regulation of Dbf4p stability. Mol Cell Biol 19: 4888-4896.

Pak DT, Pflumm M, Chesnokov I, Huang DW, Kellum R, Marr J, Romanowski P, Botchan MR. 1997. Association of the origin recognition complex with heterochromatin and HP1 in higher eukaryotes. Cell 91: 311-323.

Pelizon C, Madine MA, Romanowski P, Laskey RA. 2000. Unphosphorylatable mutants of Cdc6 disrupt its nuclear export but still support DNA replication once per cell cycle. Genes Dev 14: 2526-2533.

Perkins G, Drury LS, Diffley JF. 2001. Separate SCF ${ }^{\mathrm{CDC} 4}$ recognition elements target $\mathrm{Cdc} 6$ for proteolysis in $\mathrm{S}$ phase and mitosis. EMBO J 20: 4836-4845.

Peters JM. 2006. The anaphase promoting complex/cyclosome: A machine designed to destroy. Nat Rev Mol Cell Biol 7: 644-656.

Petersen BO, Lukas J, Sorensen CS, Bartek J, Helin K. 1999. Phosphorylation of mammalian CDC6 by cyclin A/ CDK2 regulates its subcellular localization. $E M B O J \mathbf{~ 1 8 :}$ $396-410$.

Petersen BO, Wagener C, Marinoni F, Kramer ER, Melixetian M, Lazzerini Denchi E, Gieffers C, Matteucci C, Peters JM, Helin K. 2000. Cell cycle- and cell growthregulated proteolysis of mammalian CDC6 is dependent on APC-CDH1. Genes Dev 14: 2330-2343.

Prasanth SG, Prasanth KV, Stillman B. 2002. Orc6 involved in DNA replication, chromosome segregation, and cytokinesis. Science 297: 1026-1031.

Prasanth SG, Prasanth KV, Siddiqui K, Spector DL, Stillman B. 2004. Human Orc2 localizes to centrosomes, centromeres and heterochromatin during chromosome inheritance. EMBO J 23: 2651-2663.

Prasanth SG, Shen Z, Prasanth KV, Stillman B. 2010. Human origin recognition complex is essential for HP1 binding to chromatin and heterochromatin organization. Proc Natl Acad Sci 107: 15093-15098.

Quinn LM, Herr A, McGarry TJ, Richardson H. 2001. The Drosophila Geminin homolog: Roles for Geminin in limiting DNA replication, in anaphase and in neurogenesis. Genes Dev 15: 2741-2754.

Ralph E, Boye E, Kearsey SE. 2006. DNA damage induces Cdt1 proteolysis in fission yeast through a pathway dependent on Cdt2 and Ddb1. EMBO Rep 7: 1134-1139.

Ranjan A, Gossen M. 2006. A structural role for ATP in the formation and stability of the human origin recognition complex. Proc Natl Acad Sci 103: 4864-4869.

Reimann JD, Freed E, Hsu JY, Kramer ER, Peters JM, Jackson PK. 2001. Emil is a mitotic regulator that interacts with Cdc20 and inhibits the anaphase promoting complex. Cell 105: 645-655.

Remus D, Beuron F, Tolun G, Griffith JD, Morris EP, Diffley JF. 2009. Concerted loading of Mcm2-7 double hexamers around DNA during DNA replication origin licensing. Cell 139: 719-730.

Rialland M, Sola F, Santocanale C. 2002. Essential role of human CDT1 in DNA replication and chromatin licensing. J Cell Sci 115: 1435-1440.

Rowles A, Tada S, Blow JJ. 1999. Changes in association of the Xenopus origin recognition complex with chromatin on licensing of replication origins. J Cell Sci 112: 20112018.

Rudner AD, Murray AW. 2000. Phosphorylation by Cdc28 activates the Cdc20-dependent activity of the anaphasepromoting complex. J Cell Biol 149: 1377-1390.

Saha P, Chen J, Thome KC, Lawlis SJ, Hou ZH, Hendricks M, Parvin JD, Dutta A. 1998. Human CDC6/Cdc18 associates with Orcl and cyclin-cdk and is selectively eliminated from the nucleus at the onset of S phase. Mol Cell Biol 18: $2758-2767$. 
K. Siddiqui et al.

Sanchez-Pulido L, Diffley JF, Ponting CP. 2010. Homology explains the functional similarities of Treslin/Ticrr and Sld3. Curr Biol 20: R509-R510.

Sangrithi MN, Bernal JA, Madine M, Philpott A, Lee J, Dunphy WG, Venkitaraman AR. 2005. Initiation of DNA replication requires the RECQL4 protein mutated in Rothmund-Thomson syndrome. Cell 121: 887-898.

Sansam CL, Shepard JL, Lai K, Ianari A, Danielian PS, Amsterdam A, Hopkins N, Lees JA. 2006. DTL/CDT2 is essential for both CDT1 regulation and the early G2/ M checkpoint. Genes Dev 20: 3117-3129.

Sansam CL, Cruz NM, Danielian PS, Amsterdam A, Lau ML, Hopkins N, Lees JA. 2010. A vertebrate gene, ticr, is an essential checkpoint and replication regulator. Genes Dev 24: 183-194.

Schneider BL, Yang QH, Futcher AB. 1996. Linkage of replication to start by the Cdk inhibitor Sic1. Science 272: $560-562$.

Schwab M, Lutum AS, Seufert W. 1997. Yeast Hct1 is a regulator of $\mathrm{Clb} 2$ cyclin proteolysis. Cell 90: 683-693.

Schwob E, Bohm T, Mendenhall MD, Nasmyth K. 1994. The B-type cyclin kinase inhibitor $\mathrm{p} 40^{\text {SIC1 }}$ controls the G1 to S transition in S. cerevisiae. Cell 79: 233-244.

Seki T, Diffley JF. 2000. Stepwise assembly of initiation proteins at budding yeast replication origins in vitro. Proc Natl Acad Sci 97: 14115-14120.

Senga T, Sivaprasad U, Zhu W, Park JH, Arias EE, Walter JC, Dutta A. 2006. PCNA is a cofactor for Cdt1 degradation by CUL4/DDB1-mediated N-terminal ubiquitination. $J$ Biol Chem 281: 6246-6252.

Sequeira-Mendes J, Diaz-Uriarte R, Apedaile A, Huntley D, Brockdorff N, Gomez M. 2009. Transcription initiation activity sets replication origin efficiency in mammalian cells. PLoS Genet 5: e1000446.

Shareef MM, King C, Damaj M, Badagu R, Huang DW, Kellum R. 2001. Drosophila heterochromatin protein 1 (HP1)/origin recognition complex (ORC) protein is associated with HP1 and ORC and functions in heterochromatin-induced silencing. Mol Biol Cell 12: 16711685.

Sherr CJ, Roberts JM. 2004. Living with or without cyclins and cyclin-dependent kinases. Genes Dev 18: 2699-2711.

Sheu YJ, Stillman B. 2006. Cdc7-Dbf4 phosphorylates MCM proteins via a docking site-mediated mechanism to promote S phase progression. Mol Cell 24: 101-113.

Sheu YJ, Stillman B. 2010. The Dbf4-Cdc7 kinase promotes $\mathrm{S}$ phase by alleviating an inhibitory activity in $\mathrm{Mcm} 4$. Nature 463: 113-117.

Shreeram S, Sparks A, Lane DP, Blow JJ. 2002. Cell typespecific responses of human cells to inhibition of replication licensing. Oncogene 21: 6624-6632.

Siddiqui K, Stillman B. 2007. ATP-dependent assembly of the human origin recognition complex. J Biol Chem 282: 32370-32383.

Skotheim JM, Di Talia S, Siggia ED, Cross FR. 2008. Positive feedback of G1 cyclins ensures coherent cell cycle entry. Nature 454: 291-296.

Spellman PT, Sherlock G, Zhang MQ, Iyer VR, Anders K, Eisen MB, Brown PO, Botstein D, Futcher B. 1998. Comprehensive identification of cell cycle-regulated genes of the yeast Saccharomyces cerevisiae by microarray hybridization. Mol Biol Cell 9: 3273-3297.

Stanojcic S, Lemaitre JM, Brodolin K, Danis E, Mechali M. 2008. In Xenopus egg extracts, DNA replication initiates preferentially at or near asymmetric AT sequences. Mol Cell Biol 28: 5265-5274.

Strausfeld UP, Howell M, Rempel R, Maller JL, Hunt T, Blow JJ. 1994. Cip1 blocks the initiation of DNA replication in Xenopus extracts by inhibition of cyclin-dependent kinases. Curr Biol 4: 876-883.

Strausfeld UP, Howell M, Descombes P, Chevalier S, Rempel RE, Adamczewski J, Maller JL, Hunt T, Blow JJ. 1996. Both cyclin A and cyclin E have S-phase promoting (SPF) activity in Xenopus egg extracts. J Cell Sci 109: 1555-1563.

Stuart D, Wittenberg C. 1995. CLN3, not positive feedback, determines the timing of CLN2 transcription in cycling cells. Genes Dev 9: 2780-2794.

Su TT, O'Farrell PH. 1997. Chromosome association of minichromosome maintenance proteins in Drosophila mitotic cycles. J Cell Biol 139: 13-21.

Su TT, O'Farrell PH. 1998. Chromosome association of minichromosome maintenance proteins in Drosophila endoreplication cycles. J Cell Biol 140: 451-460.

Sugimoto N, Tatsumi Y, Tsurumi T, Matsukage A, Kiyono T, Nishitani H, Fujita M. 2004. Cdt1 phosphorylation by cyclin A-dependent kinases negatively regulates its function without affecting geminin binding. J Biol Chem 279: 19691-19697.

Sugimoto N, Yoshida K, Tatsumi Y, Yugawa T, NarisawaSaito M, Waga S, Kiyono T, Fujita M. 2009. Redundant and differential regulation of multiple licensing factors ensures prevention of re-replication in normal human cells. J Cell Sci 122: 1184-1191.

Sun WH, Coleman TR, DePamphilis ML. 2002. Cell cycledependent regulation of the association between origin recognition proteins and somatic cell chromatin. EMBO J 21: 1437-1446.

Svitin A, Chesnokov I. 2010. Study of DNA replication in Drosophila using cell free in vitro system. Cell Cycle 9: 815-819.

Tada S, Li A, Maiorano D, Mechali M, Blow JJ. 2001. Repression of origin assembly in metaphase depends on inhibition of RLF-B/Cdt1 by geminin. Nat Cell Biol 3: 107-113.

Takeda DY, Parvin JD, Dutta A. 2005a. Degradation of Cdt1 during $S$ phase is Skp2-independent and is required for efficient progression of mammalian cells through $\mathrm{S}$ phase. J Biol Chem 280: 23416-23423.

Takeda DY, Shibata Y, Parvin JD, Dutta A. 2005b. Recruitment of ORC or CDC6 to DNA is sufficient to create an artificial origin of replication in mammalian cells. Genes Dev 19: 2827-2836.

Tanaka S, Diffley JFX. 2002. Interdependent nuclear accumulation of budding yeast Cdt1 and $\mathrm{Mcm} 2-7$ during G1 phase. Nat Cell Biol 4: 198-207.

Tanaka S, Umemori T, Hirai K, Muramatsu S, Kamimura Y, Araki H. 2007. CDK-dependent phosphorylation of Sld2 and Sld3 initiates DNA replication in budding yeast. $\mathrm{Na}$ ture 445: $328-332$. 
Tanaka S, Nakato R, Katou Y, Shirahige K, Araki H. 2011a. Origin association of Sld3, Sld7, and Cdc45 proteins is a key step for determination of origin-firing timing. Curr Biol 21: 2055-2063.

Tanaka T, Umemori T, Endo S, Muramatsu S, Kanemaki M, Kamimura Y, Obuse C, Araki H. 2011b. Sld7, an Sld3associated protein required for efficient chromosomal DNA replication in budding yeast. EMBO J 30: 20192030.

Tardat M, Brustel J, Kirsh O, Lefevbre C, Callanan M, Sardet C, Julien E. 2010. The histone H4 Lys 20 methyltransferase PR-Set7 regulates replication origins in mammalian cells. Nat Cell Biol 12: 1086-1093.

Tatsumi Y, Ohta S, Kimura H, Tsurimoto T, Obuse C. 2003. The ORC1 cycle in human cells: I. Cell cycle-regulated oscillation of human ORC1. J Biol Chem 278: 4152841534.

Tatsumi Y, Ezura K, Yoshida K, Yugawa T, Narisawa-Saito M, Kiyono T, Ohta S, Obuse C, Fujita M. 2008. Involvement of human ORC and TRF2 in pre-replication complex assembly at telomeres. Genes Cells 13: 1045-1059.

Thomae AW, Pich D, Brocher J, Spindler MP, Berens C, Hock R, Hammerschmidt W, Schepers A. 2008. Interaction between HMGAla and the origin recognition complex creates site-specific replication origins. Proc Natl Acad Sci 105: 1692-1697.

Thomae AW, Baltin J, Pich D, Deutsch MJ, Ravasz M, Zeller K, Gossen M, Hammerschmidt W, Schepers A. 2011. Different roles of the human Orc6 protein in the replication initiation process. Cell Mol Life Sci 68: 3741-3756.

Tung JJ, Hansen DV, Ban KH, Loktev AV, Summers MK, Adler JR III, Jackson PK. 2005. A role for the anaphasepromoting complex inhibitor Emi2/XErp1, a homolog of early mitotic inhibitor 1, in cytostatic factor arrest of Xenopus eggs. Proc Natl Acad Sci 102: 4318-4323.

Tyers M, Tokiwa G, Futcher B. 1993. Comparison of the Saccharomyces cerevisiae $\mathrm{G}_{1}$ cyclins: $\mathrm{Cln} 3$ may be an upstream activator of Cln1, Cln2 and other cyclins. EMBO J 12: $1955-1968$.

Van Hatten RA, Tutter AV, Holway AH, Khederian AM, Walter JC, Michael WM. 2002. The Xenopus Xmus101 protein is required for the recruitment of Cdc45 to origins of DNA replication. J Cell Biol 159: 541-547.

Vas A, Mok W, Leatherwood J. 2001. Control of DNA rereplication via $\mathrm{Cdc} 2$ phosphorylation sites in the origin recognition complex. Mol Cell Biol 21: 5767-5777.

Vashee S, Cvetic C, Lu W, Simancek P, Kelly TJ, Walter JC. 2003. Sequence-independent DNA binding and replication initiation by the human origin recognition complex. Genes Dev 17: 1894-1908.

Vassilev LT, Tovar C, Chen S, Knezevic D, Zhao X, Sun H, Heimbrook DC, Chen L. 2006. Selective small-molecule inhibitor reveals critical mitotic functions of human CDK1. Proc Natl Acad Sci 103: 10660-10665.

Vaziri C, Saxena S, Jeon Y, Lee C, Murata K, Machida Y, Wagle N, Hwang DS, Dutta A. 2003. A p53-dependent checkpoint pathway prevents rereplication. Mol Cell 11: 997-1008.

Verma R, Annan RS, Huddleston MJ, Carr SA, Reynard G, Deshaies RJ. 1997a. Phosphorylation of Siclp by $\mathrm{G}_{1} \mathrm{Cdk}$ required for its degradation and entry into $\mathrm{S}$ phase. Science 278: 455-460.

Verma R, Feldman RM, Deshaies RJ. 1997b. SIC1 is ubiquitinated in vitro by a pathway that requires CDC4, CDC34, and cyclin/CDK activities. Mol Biol Cell 8: 1427-1437.

Visintin R, Prinz S, Amon A. 1997. CDC20 and CDH1: A family of substrate-specific activators of APC-dependent proteolysis. Science 278: 460-463.

Visintin R, Craig K, Hwang ES, Prinz S, Tyers M, Amon A. 1998. The phosphatase Cdc14 triggers mitotic exit by reversal of Cdk-dependent phosphorylation. Mol Cell 2: 709-718.

Walter JC. 2000. Evidence for sequential action of cdc7 and cdk2 protein kinases during initiation of DNA replication in Xenopus egg extracts. J Biol Chem 275: 3977339778.

Weinreich M, Stillman B. 1999. Cdc7p-Dbf4p kinase binds to chromatin during $S$ phase and is regulated by both the $\mathrm{APC}$ and the RAD53 checkpoint pathway. EMBO J 18: 5334-5346.

Weinreich M, Liang C, Chen HH, Stillman B. 2001. Binding of cyclin-dependent kinases to ORC and Cdc6p regulates the chromosome replication cycle. Proc Natl Acad Sci 98: 11211-11217.

Whittaker AJ, Royzman I, Orr-Weaver TL. 2000. Drosophila double parked: A conserved, essential replication protein that colocalizes with the origin recognition complex and links DNA replication with mitosis and the down-regulation of S phase transcripts. Genes Dev 14: 1765-1776.

Wilmes GM, Archambault V, Austin RJ, Jacobson MD, Bell SP, Cross FR. 2004. Interaction of the S-phase cyclin Clb5 with an "RXL" docking sequence in the initiator protein Orc6 provides an origin-localized replication control switch. Genes Dev 18: 981-991.

Wohlschlegel JA, Dwyer BT, Dhar SK, Cvetic C, Walter JC, Dutta A. 2000. Inhibition of eukaryotic DNA replication by geminin binding to Cdt1. Science 290: 2309-2312.

Wohlschlegel JA, Dhar SK, Prokhorova TA, Dutta A, Walter JC. 2002. Xenopus $\mathrm{Mcm} 10$ binds to origins of DNA replication after $\mathrm{Mcm} 2-7$ and stimulates origin binding of Cdc45. Mol Cell 9: 233-240.

Wolf DA, McKeon F, Jackson PK. 1999. Budding yeast Cdc6p induces re-replication in fission yeast by inhibition of $\mathrm{SCF}^{\mathrm{Pop}-}$ mediated proteolysis. Mol Gen Genet 262: $473-$ 480.

Wong PG, Glozak MA, Cao TV, Vaziri C, Seto E, Alexandrow M. 2010. Chromatin unfolding by Cdt1 regulates MCM loading via opposing functions of $\mathrm{HBO} 1$ and HDAC11-geminin. Cell Cycle 9: 4351-4363.

Wuarin J, Buck V, Nurse P, Millar JB. 2002. Stable association of mitotic cyclin $\mathrm{B} / \mathrm{Cdc} 2$ to replication origins prevents endoreduplication. Cell 111: 419-431.

Xu X, Rochette PJ, Feyissa EA, Su TV, Liu Y. 2009. MCM10 mediates RECQ4 association with MCM2-7 helicase complex during DNA replication. EMBO J 28: 30053014.

Yabuuchi H, Yamada Y, Uchida T, Sunathvanichkul T, Nakagawa T, Masukata H. 2006. Ordered assembly of Sld3, GINS and Cdc45 is distinctly regulated by DDK 


\section{K. Siddiqui et al.}

and CDK for activation of replication origins. EMBO J 25: $4663-4674$.

Yamada Y, Nakagawa T, Masukata H. 2004. A novel intermediate in initiation complex assembly for fission yeast DNA replication. Mol Biol Cell 15: 3740-3750.

Yanagi K, Mizuno T, You Z, Hanaoka F. 2002. Mouse geminin inhibits not only Cdt1-MCM6 interactions but also a novel intrinsic Cdt1 DNA binding activity. J Biol Chem 277: 40871-40880.

Yanow SK, Lygerou Z, Nurse P. 2001. Expression of Cdc18/ Cdc6 and Cdt1 during $\mathrm{G}_{2}$ phase induces initiation of DNA replication. EMBO J 20: 4648-4656.

Zachariae W, Schwab M, Nasmyth K, Seufert W. 1998. Control of cyclin ubiquitination by CDK-regulated binding of Hctl to the anaphase promoting complex. Science 282: $1721-1724$.

Zegerman P, Diffley JF. 2007. Phosphorylation of Sld2 and Sld3 by cyclin-dependent kinases promotes DNA replication in budding yeast. Nature 445: 281-285.
Zhu W, DePamphilis ML. 2009. Selective killing of cancer cells by suppression of geminin activity. Cancer Res 69: 4870-4877.

Zhu W, Chen Y, Dutta A. 2004. Rereplication by depletion of geminin is seen regardless of p53 status and activates a $\mathrm{G}_{2} / \mathrm{M}$ checkpoint. Mol Cell Biol 24: 7140-7150.

Zhu W, Ukomadu C, Jha S, Senga T, Dhar SK, Wohlschlegel JA, Nutt LK, Kornbluth S, Dutta A. 2007. Mcm10 and And-1/CTF4 recruit DNA polymerase $\alpha$ to chromatin for initiation of DNA replication. Genes Dev 21: 2288-2299.

Zou L, Stillman B. 1998. Formation of a preinitiation complex by S-phase cyclin CDK-dependent loading of Cdc45p onto chromatin. Science 280: 593-596.

Zou L, Stillman B. 2000. Assembly of a complex containing Cdc45p, replication protein $\mathrm{A}$, and $\mathrm{Mcm} 2 \mathrm{p}$ at replication origins controlled by S-phase cyclin-dependent kinases and Cdc7p-Dbf4p kinase. Mol Cell Biol 20: 3086-3096. 


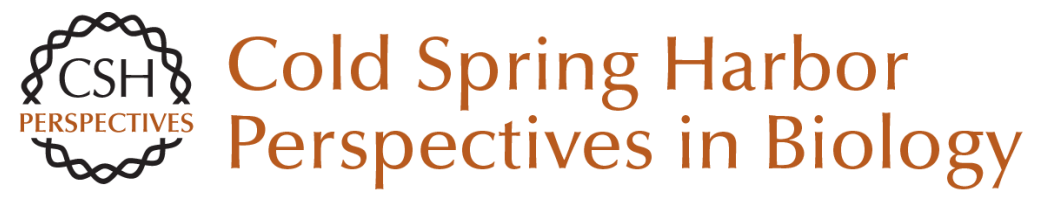

\section{Regulating DNA Replication in Eukarya}

Khalid Siddiqui, Kin Fan On and John F.X. Diffley

Cold Spring Harb Perspect Biol 2013; doi: 10.1101/cshperspect.a012930 originally published online July 9, 2013

\section{Subject Collection DNA Replication}

Replication of Epstein-Barr Viral DNA Wolfgang Hammerschmidt and Bill Sugden

Replication Proteins and Human Disease Andrew P. Jackson, Ronald A. Laskey and Nicholas Coleman

Break-Induced DNA Replication Ranjith P. Anand, Susan T. Lovett and James E. Haber

Regulating DNA Replication in Eukarya Khalid Siddiqui, Kin Fan On and John F.X. Diffley

Archaeology of Eukaryotic DNA Replication Kira S. Makarova and Eugene V. Koonin

Translesion DNA Polymerases Myron F. Goodman and Roger Woodgate

Human Papillomavirus Infections: Warts or Cancer?

Louise T. Chow and Thomas R. Broker

Chromatin and DNA Replication

David M. MacAlpine and Geneviève Almouzni
Endoreplication

Norman Zielke, Bruce A. Edgar and Melvin L.

DePamphilis

Replication-Fork Dynamics

Karl E. Duderstadt, Rodrigo Reyes-Lamothe, Antoine M. van Oijen, et al.

Helicase Activation and Establishment of

Replication Forks at Chromosomal Origins of

Replication

Seiji Tanaka and Hiroyuki Araki

Poxvirus DNA Replication Bernard Moss

The Minichromosome Maintenance Replicative Helicase

Stephen D. Bell and Michael R. Botchan

DNA Replication Origins

Alan C. Leonard and Marcel Méchali

Principles and Concepts of DNA Replication in

Bacteria, Archaea, and Eukarya

Michael O'Donnell, Lance Langston and Bruce Stillman

DNA Replication Timing

Nicholas Rhind and David M. Gilbert

For additional articles in this collection, see http://cshperspectives.cshlp.org/cgi/collection/

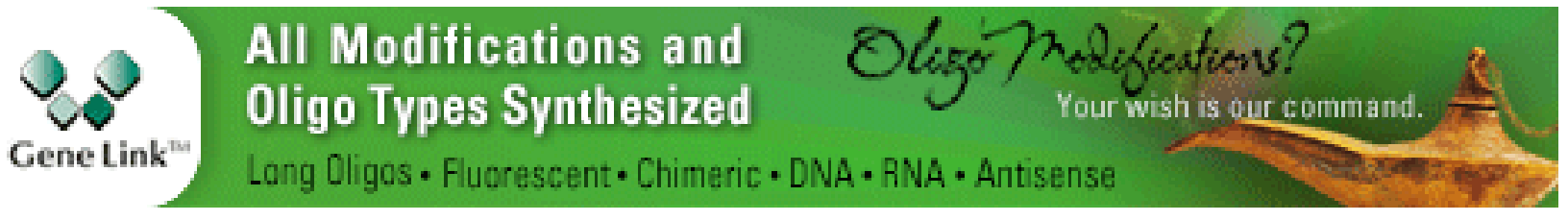

Copyright @ 2013 Cold Spring Harbor Laboratory Press; all rights reserved 